\title{
Orbitally tuned timescale and astronomical forcing in the middle Eocene to early Oligocene
}

\author{
T. Westerhold ${ }^{1}$, U. Röhl ${ }^{1}$, H. Pälike ${ }^{1}$, R. Wilkens ${ }^{2}$, P. A. Wilson ${ }^{3}$, and G. Acton ${ }^{4}$ \\ ${ }^{1}$ MARUM - Center for Marine Environmental Sciences, University of Bremen, Leobener Strasse, 28359 Bremen, Germany \\ ${ }^{2}$ Institute of Geophysics and Planetology, University of Hawaii, Honolulu, HI 96822, USA \\ ${ }^{3}$ National Oceanography Centre Southampton, University of Southampton, Waterfront Campus, European Way, \\ Southampton, SO143ZH, UK \\ ${ }^{4}$ Department of Geography and Geology, Sam Houston State University, Huntsville, TX 77431, USA \\ Correspondence to: T. Westerhold (twesterhold@marum.de)
}

Received: 12 November 2013 - Published in Clim. Past Discuss.: 18 December 2013

Revised: 18 February 2014 - Accepted: 22 March 2014 - Published: 16 May 2014

\begin{abstract}
Deciphering the driving mechanisms of Earth system processes, including the climate dynamics expressed as paleoceanographic events, requires a complete, continuous, and high-resolution stratigraphy that is very accurately dated. In this study, a robust astronomically calibrated age model was constructed for the middle Eocene to early Oligocene interval (31-43 Ma) in order to permit more detailed study of the exceptional climatic events that occurred during this time, including the middle Eocene climate optimum and the Eocene-Oligocene transition. A goal of this effort is to accurately date the middle Eocene to early Oligocene composite section cored during the Pacific Equatorial Age Transect (PEAT, IODP Exp. 320/321). The stratigraphic framework for the new timescale is based on the identification of the stable long eccentricity cycle in published and new highresolution records encompassing bulk and benthic stable isotope, calibrated XRF core scanning, and magnetostratigraphic data from ODP Sites 171B-1052, 189-1172, 1991218 , and 207-1260 as well as IODP Sites 320-U1333, and 320-U1334 spanning magnetic polarity Chrons C12n to $\mathrm{C} 20 \mathrm{n}$. Subsequently orbital tuning of the records to the La2011 orbital solution was conducted. The resulting new timescale revises and refines the existing orbitally tuned age model and the geomagnetic polarity timescale from 31 to $43 \mathrm{Ma}$. The newly defined absolute age for the EoceneOligocene boundary validates the astronomical tuned age of $33.89 \mathrm{Ma}$ identified at the Massignano, Italy, global stratotype section and point. The compilation of geochemical records of climate-controlled variability in sedimenta-
\end{abstract}

tion through the middle-to-late Eocene and early Oligocene demonstrates strong power in the eccentricity band that is readily tuned to the latest astronomical solution. Obliquity driven cyclicity is only apparent during 2.4 myr eccentricity cycle minima around 35.5, 38.3, and 40.1 Ma.

\section{Introduction}

The Eocene-Oligocene transition (EOT) was a critical turning point in Earth's climatic history $\sim 34$ million years ago. The ice-free warm world of the early Eocene shifted to one with lower greenhouse gas concentration and glacial conditions, accentuated by the growth of substantial ice sheets on Antarctica in the early Oligocene (Shackleton and Kennett, 1975; Grazzini and Oberhaensli, 1985; Pearson and Palmer, 2000; Zachos et al., 2001; Koeberl and Montanari, 2009). During this transition the carbonate compensation depth (CCD) deepened by $\sim 1.2 \mathrm{~km}$, marking one of the most pronounced perturbation during the past $\sim 150 \mathrm{myr}$ (Van Andel, 1975; Lyle et al., 2002; Pälike et al., 2012). The close association between this CCD-deepening event and rapid stepwise increase in the benthic oxygen stable isotope record indicates close coupling between carbon cycle perturbation and some combination of global cooling and growth of the Antarctic ice sheets (Coxall et al., 2005; DeConto et al., 2008; Lear et al., 2008; Liu et al., 2009; Bohaty et al., 2012). Yet the extent and stability of land ice in the "doubthouse" world (Prothero et al., 2003) of the middle 
and late Eocene remain uncertain (Prentice and Matthews, 1988; Ehrmann and Mackensen, 1992; Miller et al., 1991; Zachos et al., 1994, 1996; Edgar et al., 2007; Eldrett et al., 2007; Burgess et al., 2008). This interval in Earth's history is critical to testing climatic and evolutionary hypotheses about the deterioration of earlier Eocene conditions (Zachos et al., 2001).

Key records leading to recent breakthroughs in reconstructing the late Eocene and Oligocene epochs were those recovered during ODP Leg 199 (Lyle et al., 2002), at Site 1218 in particular (Fig. 1). Data from ODP Site 1218 permitted the development of an astronomical calibration of the entire Oligocene (Coxall et al., 2005; Wade and Pälike, 2004; Pälike et al., 2006), but low-carbonate content in uppermost Eocene sediments at this site make detailed age control less certain than for the Oligocene. Although paleomagnetic age control for these time intervals is of high quality (Lanci et al., 2004, 2005), global stratigraphic correlation is hindered by low mass accumulation rates, the absence of a detailed isotope stratigraphy, and sparser biostratigraphic control in the carbonate-poor interval. To facilitate the development of an integrated magneto- and biostratigraphic framework with a stable isotope stratigraphy, IODP Expeditions 320/321 (Pacific Equatorial Age Transect - PEAT; Pälike et al., 2010) targeted the recovery of carbonate sections with a high quality magnetostratigraphy.

Decimeter-scale features in the sedimentary record as expressed in physical properties data from Leg 199 and Exp. 320/321 sites can be correlated over hundreds of kilometers at orbital resolution (Pälike et al., 2005; Westerhold et al., 2012a; Wilkens et al., 2013). Moreover, higher sedimentation rates and better preservation of carbonate in the middle to late Eocene of Exp. 320/321 sites (hereafter referred to as PEAT records) allows tests and improvement of earlier efforts to astronomically calibrate this time interval (Pälike et al., 2006) and further extend these back into the early to middle Eocene (Westerhold et al., 2012a). High-quality shipboard paleomagnetic records (Pälike et al., 2010), revised composite records, and detailed site-to-site correlation for all PEAT sites (Westerhold et al., 2012a; Wilkens et al., 2013) are the prerequisite for further intercalibration of all major microfossil groups and refinement of magnetic polarity chrons, particularly for the Eocene.

The main focus of this study is to establish a stratigraphic framework based on the identification of the stable long eccentricity cycle (405 kyr; Laskar et al., 2004; Hinnov and Hilgen, 2012) and subsequent detailed orbital tuning of the records. New geochemical records $\left(\mathrm{CaCO}_{3}\right.$, $\mathrm{SiO}_{2}$, and $\mathrm{Fe}_{2} \mathrm{O}_{3} \mathrm{wt} \%$ obtained from calibrated XRF core scanning data; bulk stable isotope data) were generated for Site 1218 and Sites U1333/U1334 spanning magnetic polarity Chrons C12n-C20n (31-43 Ma). In combination with published data, the phase relationship of stable isotope data to XRF core scanning data is documented, a stratigraphic framework for the Bartonian, Priabonian and early Rupelian

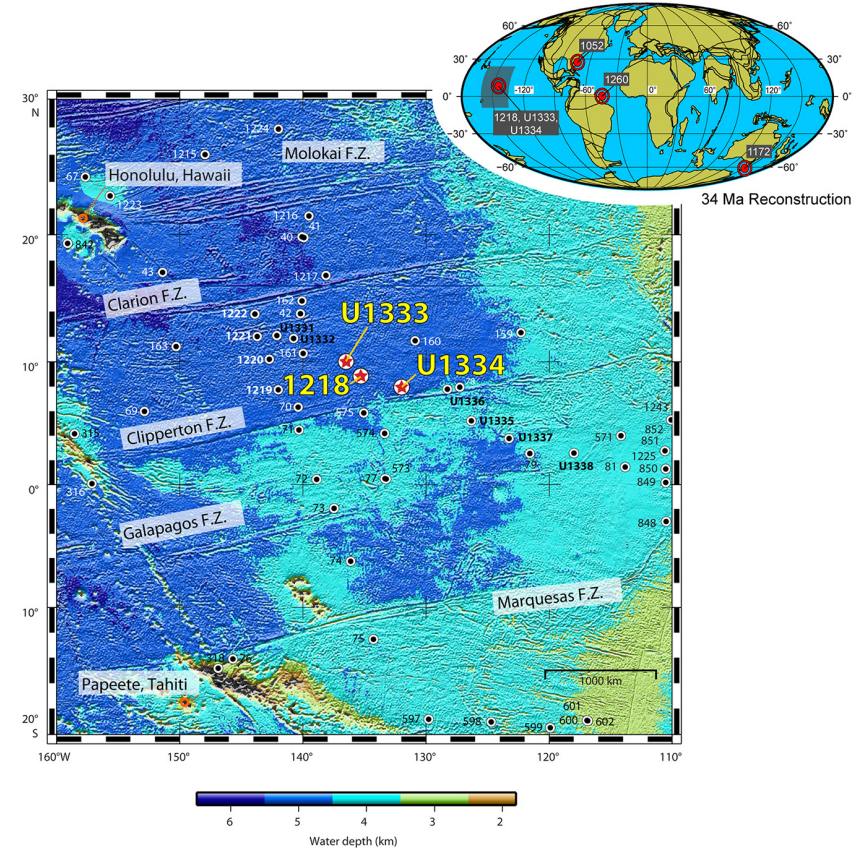

Figure 1. Location map of sites used in this study on 34 Ma paleogeographic reconstruction in Mollweide projection (ODSN, 2011; Hay et al., 1999) and detailed location map in the Pacific (big map, red stars) with additional IODP/ODP/DSDP sites. F.Z. = fracture zone (modified from Pälike et al., 2010).

Stages in the equatorial Pacific established and subsequently orbital tuning applied to the records. In this way, a fully integrated and astronomically calibrated bio-, chemo-, and magnetostratigraphy for the equatorial Pacific from 31 to $43 \mathrm{Ma}$ is now provided.

\section{Material and methods}

In addition to the new data from the PEAT records, published data from Site 1052 (ODP Leg 171B - Blake Nose, Atlantic margin of northern Florida; Pälike et al., 2001), Hole 1172A (ODP Leg 189 - East Tasman Plateau; Röhl et al., 2004), and Site 1260 (ODP Leg 207 - Demerara Rise; Westerhold and Röhl, 2013) were reinvestigated. With respect to the depth scale nomenclature "rmcd (revised CCSF-A)" is used for the revised composite core depth below seafloor at Site U1333 and U1334, and "rmcd" is used for revised meters composite depth at Site 1218 (for details on depth scale definitions see IODP, 2011 and Westerhold et al., 2012a).

\subsection{XRF core scanner data}

Sediments from Sites 1218, U1333, and U1334 were scanned using the XRF Core Scanner III (AVAATECH serial no. 12) at the MARUM - University of Bremen (Röhl and Abrams, 2000; Röhl et al., 2007; Westerhold et al., 2007). Elemental intensities (Al through $\mathrm{Fe}$ ) were collected every $2 \mathrm{~cm}$ 
down-core over a $1.2 \mathrm{~cm}^{2}$ area with a down-core slit size of $10 \mathrm{~mm}$ using generator settings of $10 \mathrm{kV}$, a current of $0.12 \mathrm{~mA}$, and a sampling time of $20 \mathrm{~s}$ at the split core surface of the archive half. The split core surface was covered with a 4-micron-thin SPEXCerti Prep Ultralene1 foil to avoid contamination of the XRF measurement unit and desiccation of the sediment. Data have been acquired by a Canberra XPIPS Detector (Model SXP 5C-200-1500 V2) with 200eV $\mathrm{X}$-ray resolution, the Canberra Digital Spectrum Analyzer DAS 1000, and an Oxford Instruments 100W Neptune Xray tube with rhodium $(\mathrm{Rh})$ target material. Raw data spectra were processed by the Analysis of X-ray spectra by iterative least square software (WIN AXIL) package from Canberra Eurisys. For cores from the Site U1333 splice, a higher energy run with $50 \mathrm{kV}$, a current of $1.0 \mathrm{~mA}$, a Cu filter, and a sampling time of $30 \mathrm{~s}$ was added in order to also record Barium $(\mathrm{Ba})$ intensity variations at $2 \mathrm{~cm}$ resolution.

We scanned cores from the revised splice at each site (Westerhold et al., 2012a) with suitable overlaps to test the accuracy of the new composite section. Scanning was undertaken on archive halves from Site 1218 covering 201.68$293.20 \mathrm{rmcd}$, from Site U1333 covering 102.39-200.43 rmcd (m revised CCSF-A), and from Site U1334 covering 205.05341.42 rmcd (m revised CCSF-A). Calcium (Ca) elemental intensity data have been transferred into carbonate wt $\%$ using $\mathrm{CaCO}_{3}$ values analyzed on discrete samples for calibration purposes (Wilson et al., unpublished). Fe and Si elemental intensity data have been quantified by calibrating normalized median scaled (NMS, Lyle et al., 2012) XRF core scanning intensity data with ED-XRF analyses (Westerhold et al., unpublished). Calibrated high-resolution XRF core scanning intensities are calculated and reported as oxides $\left(\mathrm{SiO}_{2}\right.$, $\mathrm{Fe}_{2} \mathrm{O}_{3}, \mathrm{CaCO}_{3}$ ), but for simplification we use $\mathrm{Si}, \mathrm{Fe}$, and $\mathrm{Ca}$ in the text. Raw, NMS, and calibrated NMS XRF core scanning intensity data are reported in Supplement Tables S1-S4 (Site 1218, 5304 sample points), S5-S8 (U1333, 6835), and S9-S12 (U1334, 8102) (Westerhold et al., 2013).

\subsection{Bulk stable isotope data}

Stable isotope measurements on 1369 freeze-dried powdered bulk sediment samples from Sites U1333 and U1334 were performed on a Finnigan MAT 251 mass spectrometer equipped with an automated carbonate preparation line at MARUM, University Bremen. The carbonate was reacted with orthophosphoric acid at $75^{\circ} \mathrm{C}$. Analytical precision based on replicate analyses of an in-house standard (Solnhofer Limestone) averages $0.05 \% 0(1 \sigma)$ for $\delta^{13} \mathrm{C}$. All data are reported against VPDB after calibration of the in-house standard with NBS-19. In detail, 461 samples from Site U1333 were processed spanning the interval C15n-C17n.1n (138.71-152.14 rmcd - meter revised CCSFA) and 908 samples from Site U1334 spanning the interval C16n.2n-C18n.1n (314.59-341.44 rmcd - meter revised CCSF-A). Bulk stable isotope data for U1333 and U1334 are reported in Supplement Tables S13 and S14, respectively, at http://doi.pangaea.de/10.1594/PANGAEA.821903 (Westerhold et al., 2013).

\subsection{Paleomagnetic data Site U1333}

The magnetostratigraphy for Site U1333 was originally constructed from continuous paleomagnetic measurements made every $5 \mathrm{~cm}$ along the archive-half sections of all cores collected with the advanced piston corer (APC) during Expedition 320 (Pälike et al., 2010). Magnetic cleaning typically was limited to alternating field (AF) demagnetization in peak fields of $20 \mathrm{mT}$, which was shown to be sufficient to remove drilling-related magnetic overprints and to resolve a primary depositional remanence magnetization (Pälike et al., 2010).

To determine the paleomagnetic direction more accurately and the depths of magnetic reversal boundaries more precisely, while also providing relative paleointensity estimates and environmental magnetic records, $169 \mathrm{U}$-channel samples $(2 \mathrm{~cm} \times 2 \mathrm{~cm} \times 150 \mathrm{~cm})$ were collected continuously along the spliced composite stratigraphic section from 0 to $190 \mathrm{rmcd}$. Paleomagnetic results from the lower $88 \mathrm{U}$-channel samples $(96-190 \mathrm{rmcd})$, which provide a magnetostratigraphy that spans from the middle of Chron C11r to within Chron $\mathrm{C} 20 \mathrm{n}$, are presented here. Results for the upper $81 \mathrm{U}$-channel samples (0-96 rmcd), spanning from the base of Chron C6n to the middle of Chron C11r, are presented in Guidry et al. (2013).

For the interval from 96 to $190 \mathrm{rmcd}$, each U-channel sample was subjected to progressive AF demagnetization from $0 \mathrm{mT}$ up to 80 or $100 \mathrm{mT}$ typically in $8-11$ steps and the magnetic remanence was measured every $1 \mathrm{~cm}$ following each step. Paleomagnetic directions were determined from principal component analysis (PCA) in which remanence measurements from at least five demagnetization steps for each interval were fit to lines (Kirschvink, 1980). Linear fits were well constrained, with average maximum angular deviation (MAD) angles of $2.3^{\circ}$ for the 10896 intervals used in the magnetostratigraphic interpretation (Supplement Fig. S13 and Tables S17-S19). The revised magnetostratigraphy is derived from the distinct $\sim 180^{\circ}$ alternations in magnetic declination that occur along the composite stratigraphic section (Supplement Fig. S14 and Tables S17-S19). Overall, the revised magnetostratigraphy differs very little from that obtained during Expedition 320 (Supplement Fig. S14). Most magnetozone boundaries were adjusted by $<5 \mathrm{~cm}$, with adjustments $>50 \mathrm{~cm}$ for only three of the 23 reversals between Magnetozones C11r and C20n (Supplement Document S1). This attests to the stability of the primary magnetization of these sediments. Other details of the measurements, processing, and results are provided in Supplement Document S1, with raw paleomagnetic data and the PCA paleomagnetic directions for the three holes given in Supplement Tables S17-S19. 


\section{Results}

The sediments studied consist of nannofossil ooze or chalk, radiolarite, and claystone (Pälike et al., 2010) and therefore varying amounts of carbonate, opal, and terrigenous material. Calibrated high-resolution XRF core scanning intensities show highly dynamic wt\% values in late Eocene sediments and lower amplitude variations in middle Eocene (middle of Chron $\mathrm{C} 18 \mathrm{r}-\mathrm{C} 19 \mathrm{n}$ ) and very early Oligocene (younger than Chron C13r) nannofossil chalks and oozes with $\mathrm{CaCO}_{3}$ contents averaging around $75-80 \mathrm{wt} \%$ (Fig. 2). The lower amplitude variations correspond to intervals when the CCD was relatively deep in the equatorial Pacific (Lyle et al., 2005; Pälike et al., 2012). Carbonate content drops to near zero at all sites across the $\mathrm{C} 18 \mathrm{r}-\mathrm{C} 18 \mathrm{n}$ boundary during the peak of the middle Eocene climate optimum (MECO; Bohaty and Zachos, 2003) and within Chron C15r. Variations in both XRF-derived $\mathrm{Si}$ and $\mathrm{Fe}$ are anti-correlated to the $\mathrm{Ca}$ content except for the MECO interval across the $\mathrm{C} 18 \mathrm{n} 2 \mathrm{n}-\mathrm{C} 18 \mathrm{r}$ boundary at Site 1218 . Fe mainly comes from terrigenous material, whereas the $\mathrm{Si}$ signal probably represents a mixture of radiolarian ooze with terrigenous clay. The shallowest Site U1334 contains the highest carbonate content of all PEAT records, but also contains more iron oxide than the other sites because of the relatively higher clay content (Pälike et al., 2010). In contrast, Sites 1218 and U1333 reveal a greater amount of Si averaging 40-45 wt\% in the late Eocene, dropping to $\sim 20 \mathrm{wt} \%$ during the Eocene-Oligocene Transition (EOT). The amplitude in sediment composition variations of all elements (or calculated oxides) increase simultaneously at all sites close to the Chron $\mathrm{C} 17 \mathrm{r} / \mathrm{C} 18 \mathrm{n}$ boundary, are especially pronounced at Site U1334 from the middle of Chron C16n through Chron C13r, and decrease dramatically in two steps across the EOT (Fig. 2) akin to behavior documented in the published record from Site 1218 (Coxall et al., 2005).

The bulk carbon stable isotope data (black curves in Fig. 2) show long-term increases from the top of Chron C18n.1n$\mathrm{C} 15 \mathrm{n}$, a subsequent strong decrease up to the upper Chron $\mathrm{C} 13 \mathrm{r}$, and the well-known stepped increase across the EOT (Coxall et al., 2005). Pronounced higher frequency variations are related to short $(100 \mathrm{kyr})$ and long $(405 \mathrm{kyr})$ eccentricity cycles as also observed in a latest Eocene to Oligocene benthic isotope record from Site 1218 (Pälike et al., 2006).

The phase relation between bulk carbon isotopes and XRF data is not persistent over the studied interval (see next section) complicating the tuning process. Lower carbon isotope values correspond to higher carbonate, lower $\mathrm{Si}$, and lower $\mathrm{Fe}$ contents from the middle of Chron C18r-C15n. For the interval younger than Chron $\mathrm{C} 15 \mathrm{n}$ lighter carbon isotope data correspond to lower carbonate, higher $\mathrm{Si}$, and higher Fe. This phase relation, although based on relatively lower resolution stable isotope data, most likely is also present during the interval with high carbonate content from the middle of Chron C18r to the base of Chron C19n. To establish a cyclostratigraphy, we assume that the phase relation between
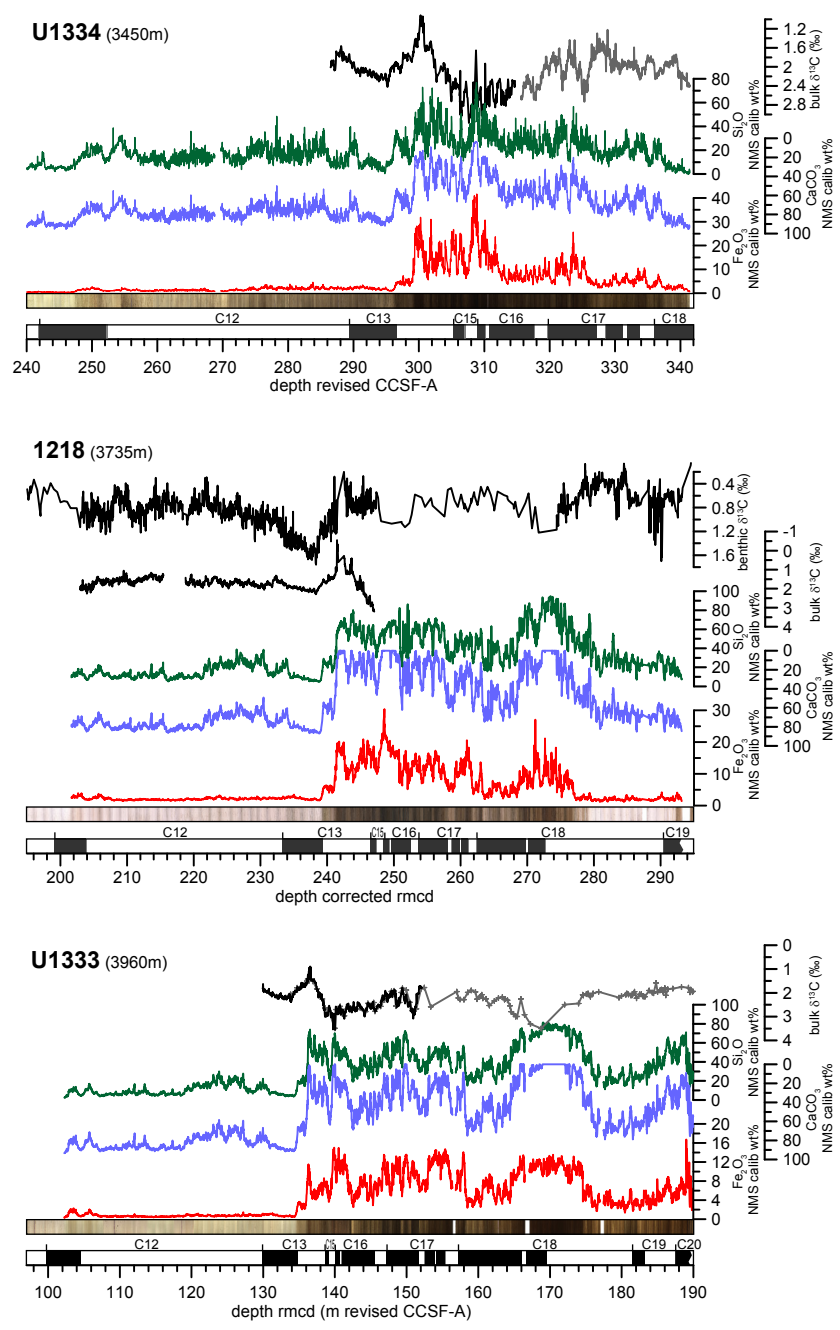

Figure 2. Overview of data from ODP Site 1218 and IODP Sites U1333/U1334 in the depth domain (in brackets the water depth of each site at $34 \mathrm{Ma}$; Pälike et al., 2010). The plots show stable carbon isotope data (black, gray), normalized median scaled (NMS) wt\% based on calibrated XRF core scanning data for Si (green), Ca (blue), and $\mathrm{Fe}$ (red) (for details see methods chapter), spliced core image, and magnetic polarity reversal pattern transferred to 1218 and U1334 by correlation to U1333 (Pälike et al., 2010; Westerhold et al., 2012a). Data sources: all XRF core scanning data from this study; bulk $\delta^{13} \mathrm{C}$ U1334 from Wilson et al. (unpublished) (black) and this study (gray), 1218 from Coxall et al. (2005) (black), U1333 from Wilson et al. (unpublished) (black), and Leon-Rodriguez and Dickens (2013) (gray); benthic (Cibicidoides spp.) $\delta^{13} \mathrm{C}$ of 1218 from Lear et al. (2004), Coxall et al. (2005), Tripati et al. (2005), and Coxall and Wilson (2011).

bulk and benthic stable isotopes and eccentricity to be constant over time. Based on results from other Paleogene successions (Lourens et al., 2005; Pälike et al., 2006; Zachos et al., 2010; Westerhold et al., 2011), it is assumed that lighter carbon isotope data in the Milankovitch frequency range (95 and $405 \mathrm{kyr}$ ) correspond to eccentricity maxima. 


\section{Cyclostratigraphic framework}

Constructing a cyclostratigraphy in late Eocene sediments is quite challenging because relatively strong changes in the CCD and accumulation rates indicates a highly dynamic environment between $\sim 39$ and $\sim 33 \mathrm{Ma}$ (Moore and Kamikuri, 2012; Pälike et al., 2010, 2012). Reworking of radiolarians at Sites 1218 and U1333 in the interval from Chron $\mathrm{C} 17 \mathrm{r}$ to the EOT poses an additional problem (Moore Jr., 2013); however, Site U1334 provides a reliable record because it is much less affected by reworking then the other two sites. The initial goal is to identify the long eccentricity cycle in the data series and undertake a basic orbital tuning to the La2011 eccentricity solution. To aid inspection of the proposed correlation to the La2011 solution long and short eccentricity cycles have been counted and a numbering scheme applied (see Supplement Fig. S8). The numbering scheme for the long eccentricity cycles ( $405 \mathrm{kyr}$ ) follows the approach of Wade and Pälike (2004), where eccentricity maxima are counted back in time (see Hinnov and Hilgen, 2012). The short eccentricity cycle ( $100 \mathrm{kyr})$ count numbers are defined as positive numbers in the Oligocene and negative numbers in the Eocene with the Eocene-Oligocene boundary defined as the starting point. Highly variable sedimentation rates mean that it is not a straightforward task to assign the short eccentricity cycle across all sites and throughout the sections. However, the integrative approach of considering three sites with multiple data records at least allows correlation of cyclostratigraphic interpretations between sites. Time-series analysis was applied as in Westerhold and Röhl (2009). Evolutionary wavelet power spectra (Wavelet software was provided by C. Torrence and G. Compo at http: //paos.colorado.edu/research/wavelets) were computed for the bulk stable $\delta^{13} \mathrm{C}$ data from Sites U1333 and U1334 (Supplement Fig. S1), and the calibrated Si, Fe, and Ca XRF core scanning data from Sites 1218, U1333, and U1334. All records are analyzed in the depth domain, and in the time domain only using magnetostratigraphy (Supplement Table S16). Because the correlation between sites can be done with high accuracy and precision (Westerhold et al., 2012a), magnetostratigraphy from U1333 is transferred or mapped to 1218 and U1334. This enables to identify the period of prominent cyclicity at all three PEAT records and evaluate the error in astronomically tuned ages for magnetochron boundaries. Due to the prominent change in lithology and accumulation rate at the EOT wavelet power spectra for the Oligocene (Supplement Figs. S2-S4) and the Eocene intervals (Supplement Figs. S5-S7) were calculated separately. For clarity of presentation time series were divided into four intervals.

\subsection{Chron C12r-C13n - early Rupelian}

The cyclostratigraphy of the carbonate-rich interval from the base of Chron C12n to the base of Chron C13n was previously constrained by the $405 \mathrm{kyr}$ cycles in the benthic stable isotope record from Site 1218 (Coxall et al., 2005; Wade and Pälike, 2004; Pälike et al., 2006; Coxall and Wilson, 2011) (Fig. 3). Improvements in the composite section (Westerhold et al., 2012a, Supplement Fig. S9) in this interval permit retuning the Site 1218 records resulting in smoother sedimentation rates than originally published (Pälike et al., 2006). The $405 \mathrm{kyr}$ cycle is apparent in the Site 1218 benthic $\delta^{13} \mathrm{C}$ record with a period of $\sim 6 \mathrm{~m}$, in Site U1334 Si data with a period of $\sim 7 \mathrm{~m}$, and in Site U1333 Si data with a period of $\sim 5 \mathrm{~m}$ (Fig. 3; Supplement Fig. S2). These periods can also be observed in the Ca record (Supplement Fig. S4). Low-Fe contents mean that cyclicity is less visible in the Fe records (Fig. 3) at sites 1218 and U1333 than at Site U1334. Long and short eccentricity minima (lighter values) in benthic and bulk $\delta^{13} \mathrm{C}$ correspond to $\mathrm{Si}$ and $\mathrm{Fe}$ maxima. Based on the pattern comparison between the La2011 solution and the benthic $\delta^{13} \mathrm{C}$ record from Site 1218 , we arrive at the same correlation of the stable $405 \mathrm{kyr}$ cycle as Pälike et al. (2006) with Chron $\mathrm{C} 12 \mathrm{r}$ and $\mathrm{C} 13 \mathrm{n}$ spanning cycles 78-83. The short eccentricity cycles are clearly present in the lower part of Chron $\mathrm{C} 12 \mathrm{r}$ and the upper part of Chron C13n, where amplitudes in $\mathrm{Si}$ and $\mathrm{Ca}$ data are more pronounced. In the upper part of Chron $\mathrm{C} 12 \mathrm{r}$ these cycle are present but less evident. We have tentatively identified these short eccentricity cycles and correlated them to La2011 (green numbers in Fig. 3). Four ash layers can be traced at all three sites and were used as independent correlation features (Kuroda and Westerhold, 2013) to further guide correlation.

\subsection{Chron C13n-C15r - Eocene-Oligocene Transition (EOT)}

The three sites investigated (Fig. 4) allow a basic cyclostratigraphy from the base of Chron $\mathrm{C} 13 \mathrm{n}$ to the base of Chron C15r, which covers the long eccentricity cycles 84 88 , with the EOT spanning cycles $84-85$. The stable $405 \mathrm{kyr}$ cycle is readily identified in the Si data at Site U1334 with a period of $\sim 3 \mathrm{~m}$, at Site 1218 with a period of $\sim 2.4 \mathrm{~m}$, and at Site U1333 with a period of $\sim 1.2 \mathrm{~m}$ (Fig. 4; Supplement Fig. S5). Bulk stable carbon isotope data also reveal a strong $405 \mathrm{kyr}$ component (Supplement Fig. S1) but not for the interval equivalent to the long eccentricity cycles $85-86$ where bulk carbon isotope data demonstrate marked site-to-site consistency but no orbital structure and are therefore not suitable for tuning. An option we chose to follow to alleviate this challenge is to use the Si data from Site U1334 to identify the long eccentricity cycles because the phase relationship (lower $\delta^{13} \mathrm{C}$ corresponds to $\mathrm{Si}$ maxima) seems consistent on the run up to this interval (Fig. 4). 


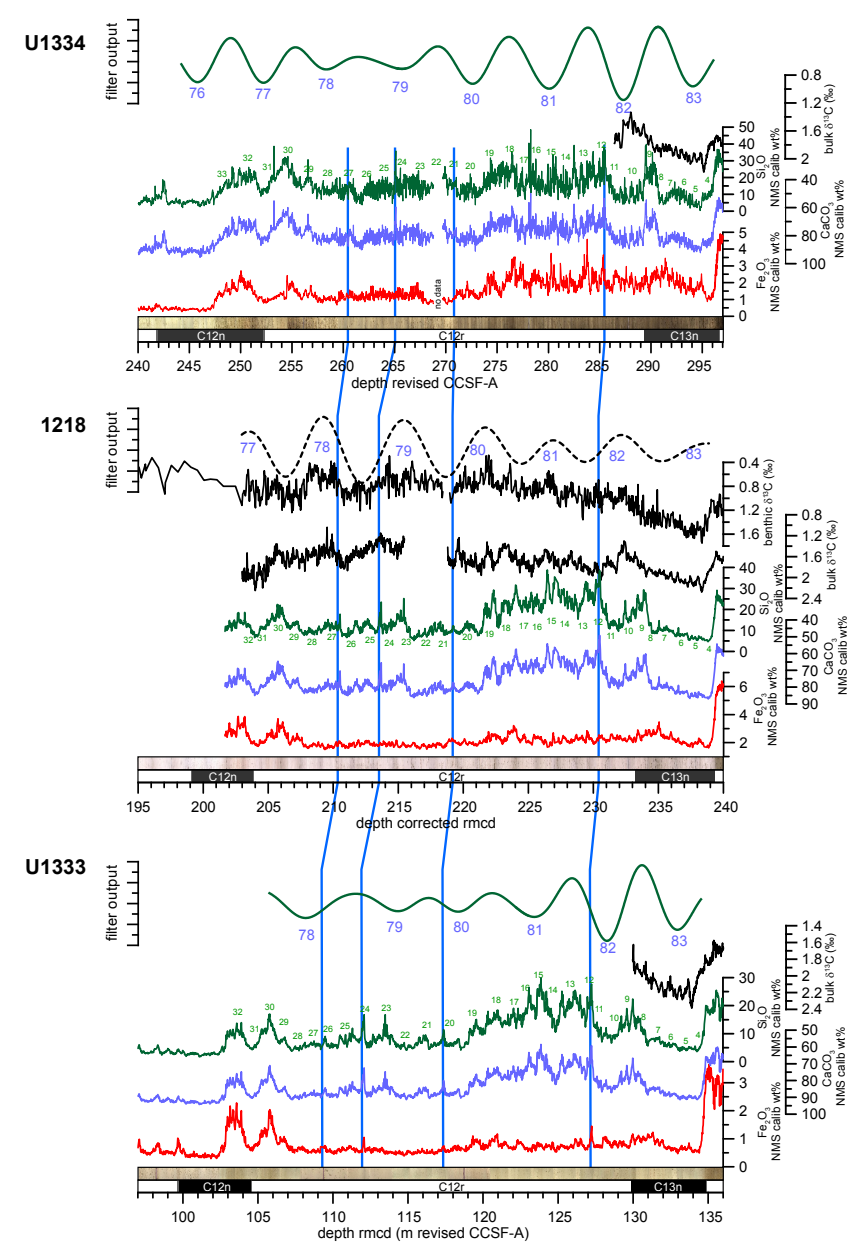

Figure 3. High-resolution XRF core scanning data, bulk and benthic stable carbon isotope data, core images and cyclostratigraphy from Chron C12n to C13n for Sites U1334, 1218, and U1333 in the depth domain. For details see captions of Fig. 2. Blue lines mark early Oligocene ash layers apparent in all three sites (Kuroda and and Westerhold, 2013). Numbers represent the assigned short (green) and long (blue) eccentricity cycle maxima positions in the orbital solution (see Supplement Fig. S8). Band pass filters: for Site U1334 from Si data $\left(0.14 \pm 0.042\right.$ cycle meter $^{-1}\left(\mathrm{c} \mathrm{m}^{-1}\right), 7.2 \mathrm{~m}$ band in Supplement Fig. S2a), for Site 1218 from benthic stable carbon isotope data $\left(0.164 \pm 0.049 \mathrm{c} \mathrm{m}^{-1}\right)$, and for Site U1333 from Si data $\left(0.2 \pm 0.06 \mathrm{c} \mathrm{m}^{-1} ; 5 \mathrm{~m}\right.$ band in Supplement Fig. S2c).

\subsection{Chron C15n-C17r - middle Priabonian to late Bartonian}

The combination of records from three equatorial Pacific sites (Fig. 5) with the ODP Site 1052 section (Fig. 6, Pälike et al., 2001) allows definition of a cyclostratigraphic framework for Chrons C15n through $\mathrm{C} 17 \mathrm{r}$ (covering long eccentricity cycles 88-95). In this interval the bulk $\delta^{13} \mathrm{C}$ and $\mathrm{Si}$ data from Sites U1333 and U1334 best resolve the $405 \mathrm{kyr}$ cyclicity. Site 1218 , however, suffers from an overall lower sedimentation rate in combination with strong carbonate dissolu-

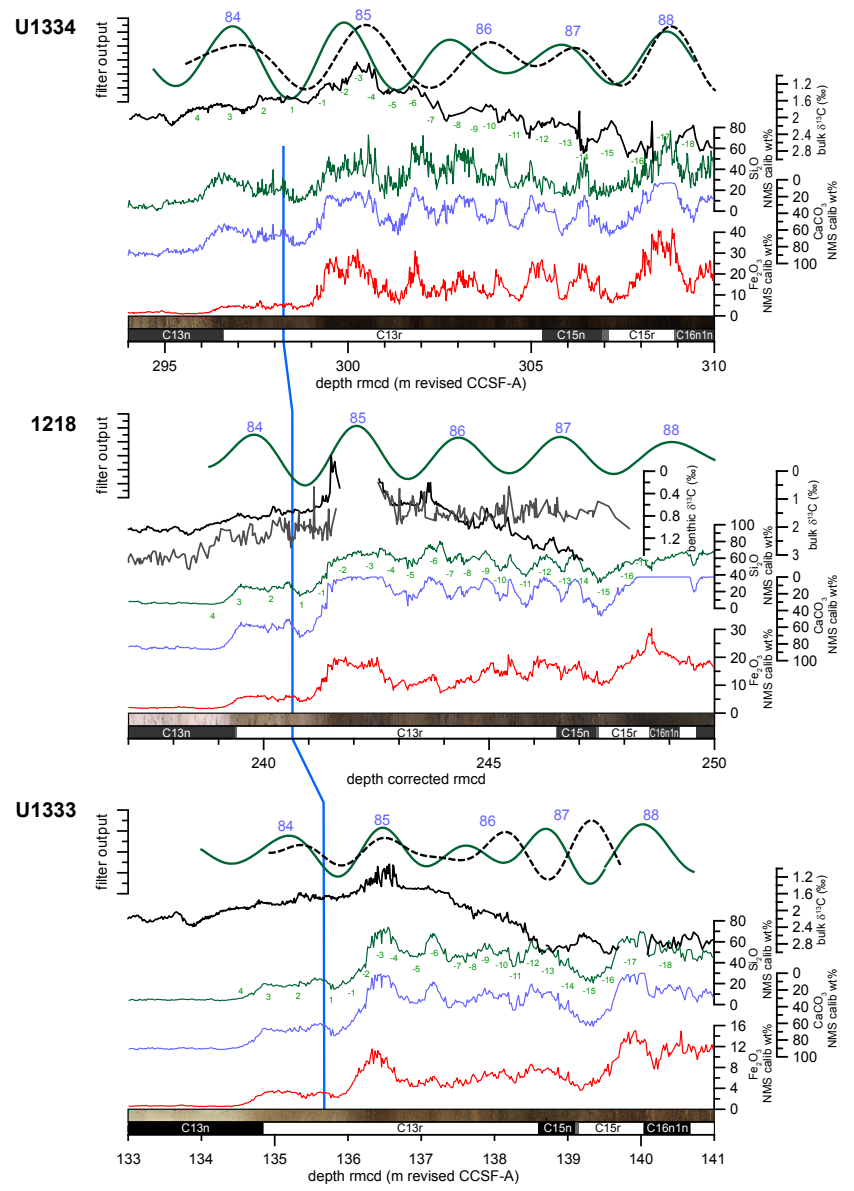

Figure 4. High-resolution XRF core scanning data, bulk and benthic stable carbon isotope data, core images, and cyclostratigraphy from Chron C13n to C15r for Sites U1334, 1218, and U1333 in the depth domain. For details see caption of Fig. 2. $405 \mathrm{kyr}$ band pass filters: for Site U1334 from Si data (green line; $0.34 \pm$ $0.102 \mathrm{c} \mathrm{m}^{-1} ; 2.95 \mathrm{~m}$ band in Supplement Fig. S5a) and bulk stable carbon isotopes (dashed black line; $0.33 \pm 0.099 \mathrm{c} \mathrm{m}^{-1} ; 3.03 \mathrm{~m}$ band in Supplement Fig. S1a); for Site 1218 from Si data (0.42 \pm $0.126 \mathrm{c} \mathrm{m}^{-1} ; 2.38 \mathrm{~m}$ band in Supplement Fig. S5b); for Site U1333 from Si data (green, $0.82 \pm 0.25 \mathrm{c} \mathrm{m}^{-1} ; 1.22 \mathrm{~m}$ band in Supplement Fig. S5c) and bulk stable carbon isotopes (dashed black line; $0.82 \pm$ $0.25 \mathrm{c} \mathrm{m}^{-1} ; 1.22 \mathrm{~m}$ band in Supplement Fig. S1b). Blue line marks the Eocene-Oligocene boundary (defined as $14 \%$ down in $\mathrm{C} 13 \mathrm{r}-$ C13r.14).

tion notably around $250 \mathrm{rmcd}$, long eccentricity cycle $88-89$ (Fig. 5). Both sites, 1218 and U1333, exhibit prominent fluctuations in $\mathrm{Si}, \mathrm{Ca}$, and $\mathrm{Fe}$ values due to frequent and substantial CCD changes. In contrast, the shallower Site U1334 contains on average $70 \mathrm{wt} \%$ carbonate from Chron $\mathrm{C} 17 \mathrm{r}$ up to C16n.2n. Carbonate dissolution accompanied by elevated $\mathrm{Si}$ and $\mathrm{Fe}$ values also occurs at all sites around the Chron C16n$\mathrm{C} 15 \mathrm{r}$ boundary (eccentricity cycle 88 ). The long eccentricity cycle can be clearly assigned in the bulk $\delta^{13} \mathrm{C}$ data from Sites $\mathrm{U} 1333$ and $\mathrm{U} 1334$ with a period of $\sim 2.3 \mathrm{~m}$ and $\sim 3.8 \mathrm{~m}$, re- 


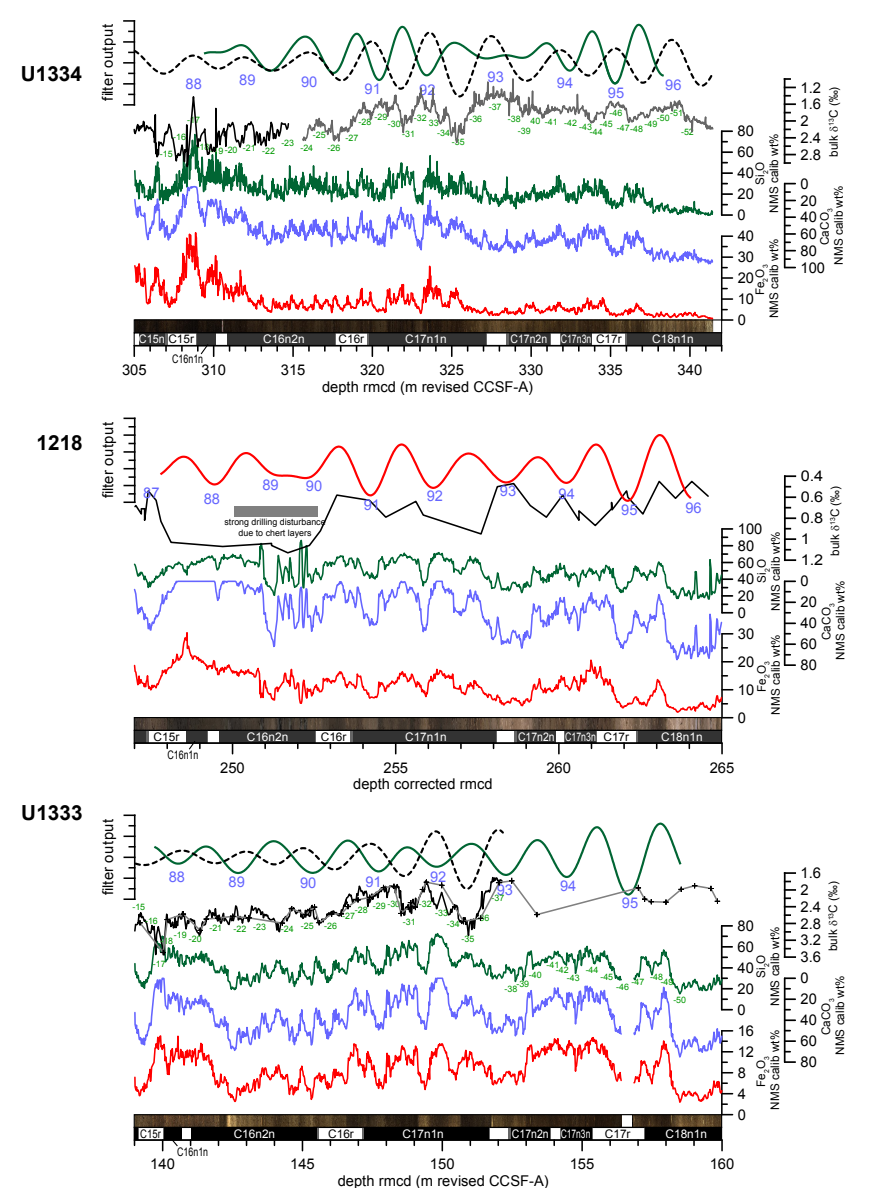

Figure 5. High-resolution XRF core scanning data, bulk and benthic stable carbon isotope data, core images, and cyclostratigraphy from Chron C15r to C18n.1n for Sites U1334, 1218, and U1333 in the depth domain. For details see caption of Fig. 2. $405 \mathrm{kyr}$ band pass filters: for Site U1334 from Si data (green line; $0.26 \pm$ $0.075 \mathrm{c} \mathrm{m}^{-1} ; 3.85 \mathrm{~m}$ band in Supplement Fig. S5a) and bulk stable carbon isotopes (dashed black line; $0.26 \pm 0.075 \mathrm{c} \mathrm{m}^{-1} ; 3.85 \mathrm{~m}$ band in Fig. S1a); for Site 1218 from Fe data $\left(0.48 \pm 0.14 \mathrm{c} \mathrm{m}^{-1}\right.$; $2.08 \mathrm{~m}$ band in Fig. S6b); for Site U1333 from Si data (green, $0.43 \pm 0.13 \mathrm{c} \mathrm{m}^{-1} ; 2.33 \mathrm{~m}$ band in Fig. S5c) and bulk stable carbon isotopes (dashed black line; $0.43 \pm 0.13 \mathrm{c} \mathrm{m}^{-1} ; 2.33 \mathrm{~m}$ band in Supplement Fig. S1b).

spectively (Fig. 5, Supplement Fig. S1). In this time interval the long eccentricity-related lower values in bulk $\delta^{13} \mathrm{C}$ correspond to $\mathrm{Si}$ and $\mathrm{Fe}$ minima and $\mathrm{Ca}$ maxima (Fig. 5). The cyclostratigraphy based on the $\delta^{13} \mathrm{C}$ data from Sites U1334 and $\mathrm{U} 1333$ is consistent with the extracted cyclicity in the $\mathrm{Fe}$ record from Site 1218. At Site U1334 a shift in phase relation occurs at $317 \mathrm{rmcd}$ (m revised CCSF-A) close to the base of C16n.2n. This shift is not observed at Sites U1333 and 1218, which indicates that the cyclostratigraphy for Chron C16 may remain indistinct.

Although ODP Site 1052 has poor quality shipboard paleomagnetic data (Shipboard Scientific Party, 1998) shore-

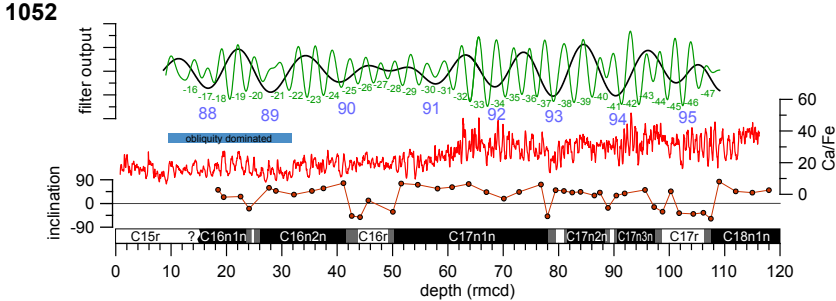

Figure 6. Cyclostratigraphy from Chron $\mathrm{C} 15 \mathrm{r}$ to $\mathrm{C} 18 \mathrm{n}$.1n for ODP Site 1052 in the depth domain. $\mathrm{Ca} / \mathrm{Fe}$ data, revised depth scale and paleomagnetic reversal pattern with errors from Pälike et al. (2001), inclination data from Ogg and Bardot (2001). Numbers represent the assigned short (green) and long (blue) eccentricity cycle maxima positions in the orbital solution (see Supplement Fig. S8). Band pass filters: $405 \mathrm{kyr}$ filter in black $\left(0.09 \pm 0.027 \mathrm{c} \mathrm{m}^{-1}\right) ; 100 \mathrm{kyr}$ filter in green $\left(0.32 \pm 0.096 \mathrm{c} \mathrm{m}^{-1}\right)$. Please note the strong obliquity component present from 10 to $30 \mathrm{rmcd}$ in the 1052 sedimentary record.

based work could identified the position of magnetochrons C16r, C17r, and C18r (Ogg and Bardot, 2001; Fig. 6). After revision of the depth scale, Pälike et al. (2001) re-evaluated the data and presented a more detailed magnetic stratigraphy spanning from $\mathrm{C} 15 \mathrm{r}$ down to $\mathrm{C} 18 \mathrm{n} .2 \mathrm{n}$ (Fig. 6). Because the shipboard data are of poor quality, we consider the magnetic stratigraphy at 1052 only reliable for base C16n.2n, top C17n.1n, base C17n.3n, and top C18n. $1 \mathrm{n}$ based on the shorebased data of Ogg and Bardot (2001). The chron-boundary $\mathrm{C} 15 \mathrm{r}-\mathrm{C} 16 \mathrm{n} .1 \mathrm{n}$ is likely documented around $12 \mathrm{rmcd}$ in the 1052D shipboard data but not backed up by shore based samples. Thus we assume that Chron $\mathrm{C} 16$ ends above $\sim 14 \mathrm{rmcd}$. The XRF core scanning data (Pälike et al., 2001) show well expressed eccentricity-modulated precession cycles (except for a $\sim 600 \mathrm{kyr}$ period in the upper part of Chron C16n with obliquity dominance) (Fig. 6). The long eccentricity cycle at Site 1052 encompasses $\sim 11 \mathrm{~m}$ intervals in the $\mathrm{Ca} / \mathrm{Fe}$ XRF core scanning data. The obliquity-dominated interval in C16n (Pälike et al., 2001) lies within cycle 88 and upper cycle 89 .

In both the La2010 and La2011 solutions, the long eccentricity cycle 88 is one of the prominent 2.4 myr long eccentricity cycle nodes with very low-amplitude modulation of eccentricity. The orbital configuration of low eccentricity in combination with observed high obliquity amplitudes in the data has also been observed in early Eocene records (Westerhold and Röhl, 2009) and could be an indication of the increased influence of high-latitude processes on lowlatitude deep ocean chemistry during minima in the $2.4 \mathrm{myr}$ eccentricity cycle. Although a precise cyclostratigraphy for Chron C16n is not feasible with the records at hand, the integration of the cyclostratigraphic results suggests that Chron C16n.1n is located within cycle 88 . 


\subsection{Chron C17r-C20n - Bartonian to late Lutetian}

To establish a reliable cyclostratigraphy for equatorial Pacific sites covering Chron C17r through C20n data from Sites 1218 and U1333 have been integrated with records from Site 1260 (ODP Leg 207, Demerara Rise; Westerhold and Röhl, 2013) and Hole 1172A cyclostratigraphies (ODP Leg 189, East Tasman Plateau, Röhl et al., 2004) (Fig. 7). This step is needed because of strong dissolution during the MECO (Bohaty and Zachos, 2003) interval ( $\sim 170 \mathrm{rmcd}$ in the Site U1333 record and $\sim 273 \mathrm{rmcd}$ in the Site 1218 section) at both PEAT sites, the lack of high-quality, high-resolution stable isotope data for the entire interval, and pronounced changes in sedimentation rate between the short eccentricity cycle -70 and -69 .

The magnetostratigraphy for ODP Site 1260 first was develop by the Shipboard Scientific Party (2004) and then refined by shore-based discrete samples (Suganuma and Ogg, 2006). Additionally, Edgar et al. (2007) analyzed a total number of 100 samples at $20-30 \mathrm{~cm}$ resolution across each of the magnetic reversals using the same method of "polarity rating" from rotary cores where the magnetic overprint is used to determine declination (and hence polarity) in the lowpaleolatitude (low inclination) data.

The shipboard data magnetic stratigraphies at ODP Site 1172 in the relevant interval (Fig. F19, in Shipboard Scientific Party, 2001) indicates very poorly defined magnetic stratigraphy. Despite this difficulty Fuller and Touchard (2004) identified the positions of the top of C18n.1n, top of C18n.2n, and base C18n.2n for Site 1172A. Subsequently, the reversal pattern was slightly revised in Röhl et al. (2004, see Fig. 6 therein) and used for cyclostratigraphy. Based on the shipboard inclination data (Supplement Fig. S10) only the top C18n.1n can be identified reliably. Base of C18n.1n and the boundaries of $\mathrm{C} 18 \mathrm{n} .2 \mathrm{n}$ cannot be defined in 1172A based on these data. Compilation of bio-, chemo-, and magnetostratigraphic data for the time encompassing the middle Eocene climate optimum (MECO; Bohaty et al., 2009) showed that the distinct carbon isotope excursion (CIE) at the end of the MECO is close to the base of C18n.2n. Comparison of bulk stable carbon isotope data from 1172A (Bijl et al., 2010) with the magnetostratigraphy (Edgar et al., 2010) and bulk stable carbon isotope data of Site 1051 (Bohaty et al., 2009) (Supplement Fig. S10) suggests that the base of $\mathrm{C} 18 \mathrm{n} .2 \mathrm{n}$ in $1172 \mathrm{~A}$ should be indeed located at around $415 \mathrm{~m}$ b.s.f. (metres below seafloor) as proposed by Fuller and Touchard (2004). However, the exact astronomical calibration of the base of $\mathrm{C} 18 \mathrm{n} .2 \mathrm{n}$ using $1172 \mathrm{~A}$ is not reliable and needs to be refined by other records. Due to the good correlation of the CIE in the peak-MECO and the base of C18n.2n (Bohaty et al., 2009; Supplement Fig. S10) in various records, a relatively good estimate for the duration of $\mathrm{C} 18 \mathrm{n}$ can still be achieved on the eccentricity level.
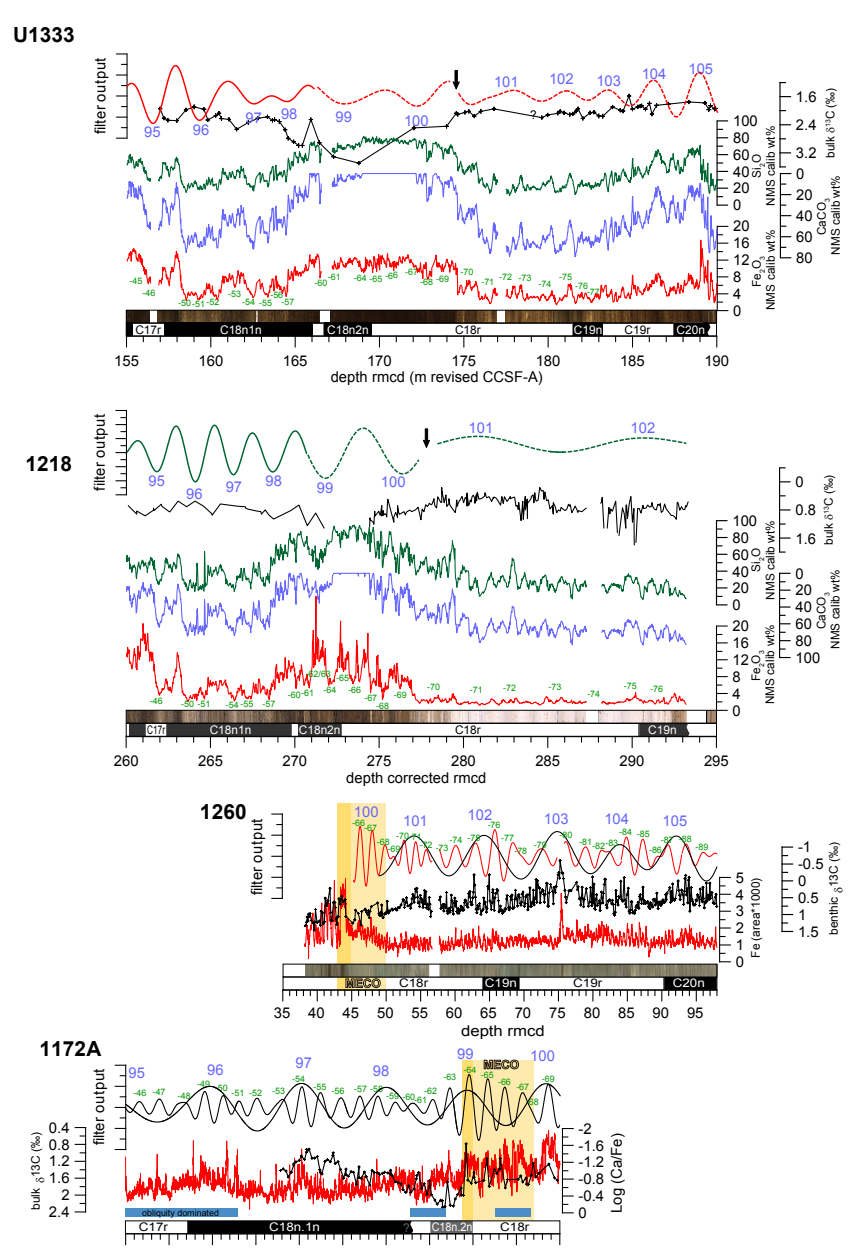

Figure 7. High-resolution XRF core scanning data, bulk and benthic stable carbon isotope data, core images, and cyclostratigraphy from Chron C18n.1n to C20n for Sites U1333, 1218, 1260, and Hole 1172A in the depth domain. For details see caption of Fig. 2. ODP Site 1260 XRF Fe intensity data from Westerhold and Röhl (2013), benthic stable isotope data, and magnetostratigraphy from Edgar et al. (2007). ODP 1172A XRF data from Röhl et al. (2004), bulk $\delta^{13} \mathrm{C}$ data from Bijl et al. (2010). Extend of the MECO is marked by a light orange bar and the carbon isotope excursion at the end of the MEO is marked by a orange bar in 1260 and 1172A (for correlation details see Supplement Fig. S10). Arrows mark change in phase relation between stable isotope and XRF core scanning data. $405 \mathrm{kyr}$ band pass filters: for Site U1333 from Fe data $\left(155-165 \mathrm{rmcd} 0.36 \pm 0.110 \mathrm{c} \mathrm{m}^{-1} ; 165-\right.$ $175 \mathrm{rmcd} 0.25 \pm 0.07 \mathrm{c} \mathrm{m}^{-1} ; 175-190 \mathrm{rmcd} 0.36 \pm 0.1 \mathrm{c} \mathrm{m}^{-1} ; 2.78$, 4, and $2.78 \mathrm{~m}$ bands in Fig. S6c); for Site 1218 from Si data (260$270 \mathrm{rmcd} 0.42 \pm 0.105 \mathrm{c} \mathrm{m}^{-1} ; 270-278 \mathrm{rmcd} 0.22 \pm 0.05 \mathrm{c} \mathrm{m}^{-1}$; $278-293 \mathrm{rmcd} 0.11 \pm 0.027 \mathrm{c} \mathrm{m}^{-1} ; 2.38,4.55$, and $9.09 \mathrm{~m}$ bands in Supplement Fig. S5b); for Site 1260 from benthic stable carbon isotope data $\left(0.1 \pm 0.03 \mathrm{c} \mathrm{m}^{-1}\right)$; and for Hole $1172 \mathrm{~A}$ from $\log (\mathrm{Ca} / \mathrm{Fe})$ data $\left(0.1 \pm 0.03 \mathrm{c} \mathrm{m}^{-1}\right)$. Note the dominant obliquity component in Hole 1172A. 
At Sites 1260 and 1172, the $\sim 10 \mathrm{~m}$ long-eccentricity cycles can be extracted from benthic isotope data (Edgar et al., 2007) and XRF core scanning $\mathrm{Ca} / \mathrm{Fe}$ data (Röhl et al., 2004). This provides a solid framework for Chron C18 and C19 spanning long eccentricity cycles 96-105 (Supplement Fig. S8). At Sites 1218 and U1333 the long eccentricity cycle can be identified in $\mathrm{Si}$ and $\mathrm{Fe}$ data as far as Chron C18n.1r with a length of $\sim 2.4$ and $\sim 2.8 \mathrm{~m}$, respectively (Fig. 7, Supplement Figs. S5 and S6). The sparse stable isotope data available for this interval still suggest that the phase relation to $\mathrm{Si}, \mathrm{Fe}$, and $\mathrm{Ca}$ is the same as in the previously discussed interval. Thus, for the interval from short eccentricity cycle -45 to -69 we assumed the same phase relation and tried to identify the $405 \mathrm{kyr}$ cycles by correlating the equatorial Pacific records to those from Sites 1260 and 1172. At Site 1218 the sedimentation rates drop from $\sim 1.5$ to $\sim 0.5 \mathrm{~cm} \mathrm{kyr}^{-1}$ and at Site U1333 from $\sim 1.0$ to $\sim 0.5 \mathrm{~cm} \mathrm{kyr}^{-1}$ (Supplement Fig. S11) during short eccentricity cycle -70 leading into the MECO. According to depth backtracking Site 1218 (3152 mb.s.l.) was almost $400 \mathrm{~m}$ shallower than Site U1333 (3533 m b.s.l.) during the top of Chron C19n (Pälike et al., 2010), which may explain why the sedimentation rate at Site 1218 is much higher than at Site U1333. The correlation suggests that the $405 \mathrm{kyr}$ cycle in the Site 1218 record has a length of $\sim 9.1 \mathrm{~m}$ starting at C19n to short eccentricity cycle -70 , and $\sim 4.5 \mathrm{~m}$ from there up to the top of C18n.2n (Fig. 7). At Site U1333 the $405 \mathrm{kyr}$ cycle has a length of $\sim 2.7$ and $\sim 4.0 \mathrm{~m}$ in the respective intervals. This implies an increase in sedimentation rates at Site U1333 during the MECO that is not visible in the Site 1218 record. However, the MECO interval was only cored in a single hole at Site U1333 (Westerhold et al., 2012a). The high sedimentation rates could be an artifact if the upper part of Core U1333A-18X covering the MECO was artificially stretched by coring.

In order to compare the geological data with orbital solutions and subsequently anchor the floating $405 \mathrm{kyr}$ stratigraphic framework in absolute time by orbital tuning, the observation of a dominant obliquity component in Hole 1172A (Röhl et al., 2004) during long eccentricity cycles 95 and 96 as well as between cycle 99 and 100 (Fig. 7) is very important. As observed in the early to middle Eocene at ODP Site 1258 (Westerhold and Röhl, 2009) an orbital configuration of low eccentricity in combination with high obliquity amplitudes during 2.4 myr eccentricity minima could have fostered the development of obliquity-dominated intervals. Therefore, the dominant obliquity component intervals in $1172 \mathrm{~A}$ can help to identify the position of 2.4 myr eccentricity cycle minima in the geological data and are important features for evaluating the accuracy of orbital solutions for eccentricity.

\section{Astronomical tuning}

Astronomical tuning, the correlation of cyclic variations in the geological record to astronomical computations of solar insolation on Earth, depends on the accuracy of the orbital target curves and the completeness of the geological data set to be calibrated. Because of uncertainties in radioisotopic dating (Westerhold et al., 2012b) and limits of astronomical calculations (Laskar et al., 2004, 2011a, 2011b) first an independent stratigraphic framework based on the identification of the stable long eccentricity cycle was developed. Subsequently, the geological data of Sites 1218, U1333, and U1334 were tuned to the La2011 orbital solution for Earth's eccentricity starting in the early Oligocene, which has been anchored to the astronomically tuned Neogene timescale (Lourens et al., 2004; Pälike et al., 2006).

The strength of obliquity cycles in the $\mathrm{Ca} / \mathrm{Fe}$ data series from Site 1052 (Pälike et al., 2001) (Fig. 6) in Hole 1172A (Röhl et al., 2004) (Fig. 7) during minima in the 2.4 myr eccentricity cycle at $35.4 \mathrm{Ma}$ (cycle 88 ) and $38.2 \mathrm{Ma}$ (cycle 95) suggests that orbital solutions and geological data are consistent with one another for this time interval. For consistency in orbital tuning procedures an astronomical target curve combining eccentricity, tilt, and precession (ETP) was used as described in Pälike et al. (2006). The La2011 eccentricity and the La2004 values for precession and obliquity were applied. Basically, the La2011 and La2004 eccentricity solutions are almost identical up to $42 \mathrm{Ma}$ with only minor deviations in the 2.4 myr eccentricity minima (Westerhold et al., 2012b). Currently there is no precession and obliquity target available based on La2011, thus the available curves were combined. To achieve a consistent age model between all sites all available information were utilized and age tie points for each site defined separately. This way an accurate astronomically calibrated timescale for the middle Eocene to early Oligocene (31-43 Ma) interval for the PEAT sites and Site 1218 (age tie points are given in Supplement Table S15) was developed. Sedimentation rates based on the astronomical calibration are relatively smooth (Fig. 8). New age estimates and durations for the geomagnetic polarity timescale are presented in Tables 1 and 2 (detailed PEAT magnetostratigraphy in Supplement Table S16) and discussed below.

\section{Discussion}

Absolute age calibration of the middle to late Eocene interval is not a straightforward matter because of the uncertainties in the exact position of ash layers with respect to magnetostratigraphy in continental sections, the uncertainty in radioisotopic dating, and the sparse coverage with highquality carbonate rich deep sea drill cores (see detailed discussion in Hilgen and Kuiper, 2009; Vandenberghe et al., 2012; Westerhold et al., 2012b). Here, the focus is the construction of a cyclostratigraphic framework based on the 


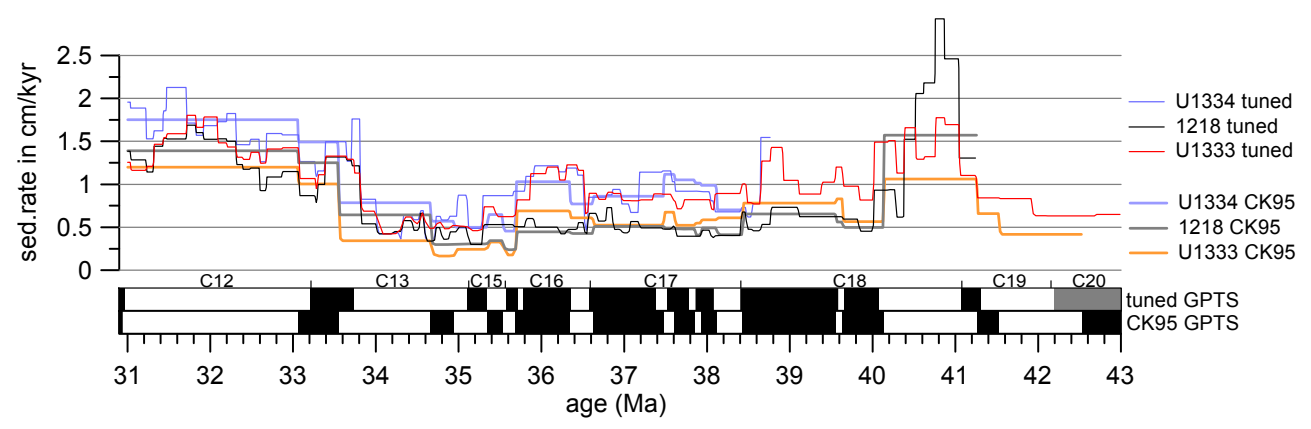

Figure 8. Sedimentation rate estimate in $\mathrm{cm} \mathrm{kyr}^{-1}$ based on astronomical tuning compared with paleomagnetic based estimates using the timescale of Cande and Kent (1995, CK95). For reference the CK95 and tuned GPTS (this study) are drawn.

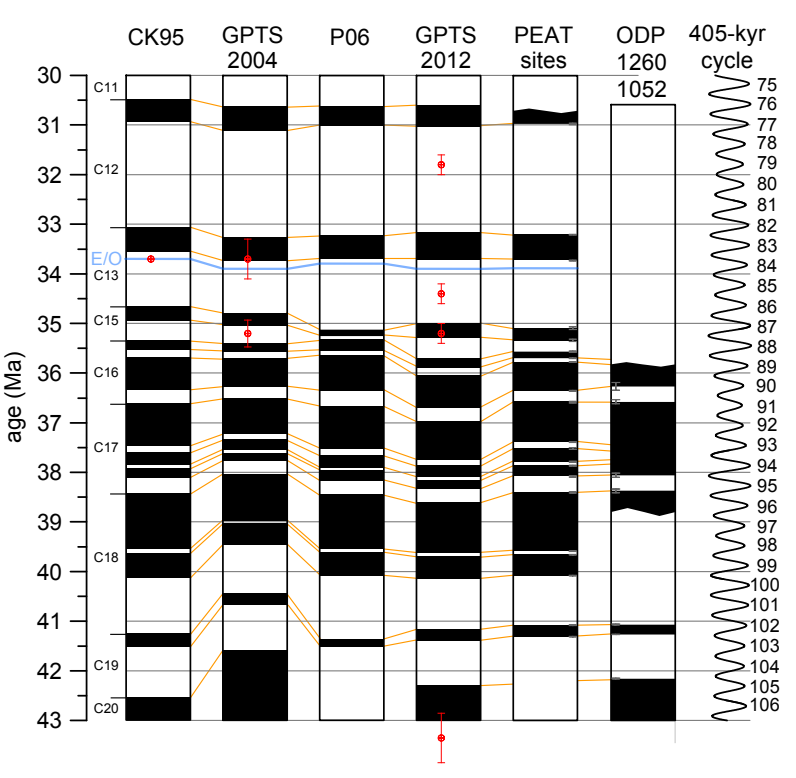

Figure 9. Comparison of magnetochron boundary ages and durations for Chron $\mathrm{C} 12$ to $\mathrm{C} 19$ based on estimates from Cande and Kent (1995; CK95), Ogg and Smith (2004; GPTS 2004), Pälike et al., (2006; P06), Ogg (2012; GPTS 2012), Pacific Equatorial Age Transect (PEAT; this study), and combined ODP Sites 1052 and 1260 (this study). Orange lines track changes between different estimates. Calibration points with error bar used by CK95, GPTS2004 and GPTS2012 are plotted in red dots. Also given is the respective absolute age of the Eocene-Oligocene boundary (E-O; blue line) and the long eccentricity cycle number for reference (see Supplement Fig. S8).

identification of the stable long eccentricity cycle (405 kyr) in deep-sea records for the middle Eocene to early Oligocene (31-43 Ma).

\subsection{Duration of magnetochrons and comparison to standard geomagnetic polarity timescales}

This new stratigraphic framework provides estimates of the absolute ages of magnetic polarity Chrons $\mathrm{C} 12 \mathrm{r}-\mathrm{C} 20 \mathrm{n}$ and their positions in the $405 \mathrm{kyr}$ cycle number scheme. Based on the multiple site approach the data set can be considered stratigraphically complete to the long eccentricity cycle level. Astronomically tuning to the La2011 orbital solution allows to refine age estimates down to the $100 \mathrm{kyr}$ level. The ages of magnetochron boundaries are accurate; only for Chron C15n and the top of C16n.1n does some uncertainty still exist.

In the early Oligocene interval, comparison of the new ages with published GPTS ages (Fig. 9, Table 1) shows that the ages are very close to those derived from previous orbital tuning of Site 1218 (Pälike et al., 2006) down to the E-O boundary. The GSSP for the Eocene-Oligocene (EO) boundary in Massignano is defined at the layer holding the extinction of the Hantkeninidae (Premoli Silva and Jenkins, 1993). This group of planktonic foraminifers is not preserved in the investigated equatorial Pacific sites. Because it is currently unknown whether or not the top of the Hantkeninidae is synchronous between the Massignano section and the equatorial Pacific sites we assume that the EO boundary occurs $14 \%$ down in Chron C13r (as given in Luterbacher et al., 2004). This results in an astronomically tuned absolute age for the E-O boundary of $33.89 \mathrm{Ma}$, which is $\sim 100 \mathrm{kyr}$ older than the age in Pälike et al. (2006). Pearson et al. (2008) placed the Hantkenina extinction on the $\delta^{18} \mathrm{O}$ plateau from Tanzania just after $\delta^{18} \mathrm{O}$ step 1. Based on the correlation between the Tanzania record and ODP Site 1218 (Pearson et al., 2008), we arrive at the same age of $33.89 \mathrm{Ma}$ for the E-O boundary in the PEAT sites. This validates the astronomical tuned age from the Massignano, Italy, global stratotype section and point (GSSP) (Brown et al., 2009).

In the middle to late Eocene interval down to Chron C18r, ages are close to the ages of Cande and Kent (1995, CK95) and Pälike et al. (2006) but are about 300 kyr younger than the ages given by GPTS2012 (Ogg, 2012; Vandenberghe et al., 2012) for all reversals from the base of Chron C15r to the base of Chron C17r. Figure 9 shows that GPTS2004 has younger and much shorter durations of magnetochrons between 35 and $41 \mathrm{Ma}$ than the other timescales. The GPTS2004 compresses the middle to late Eocene chrons 


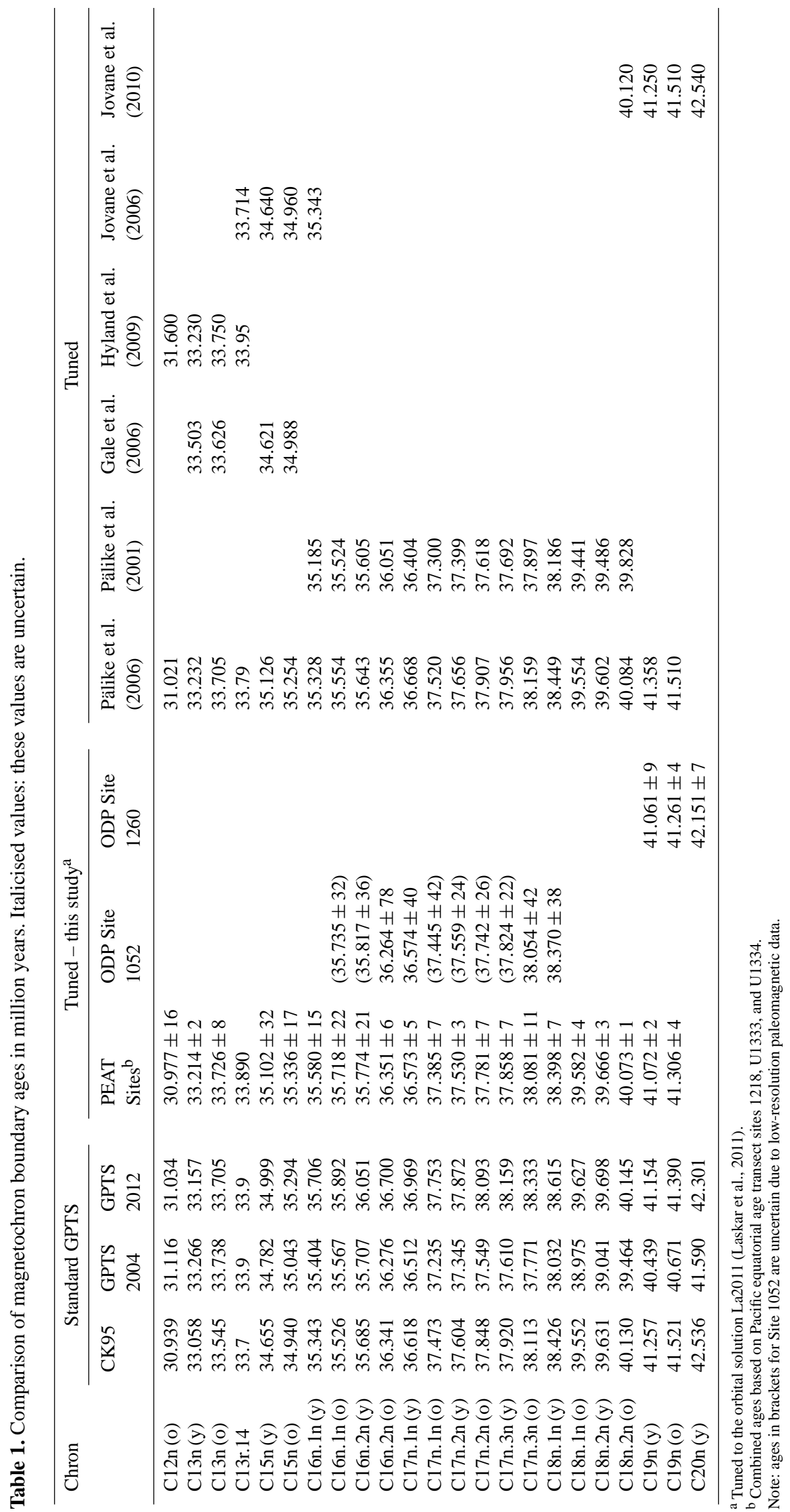




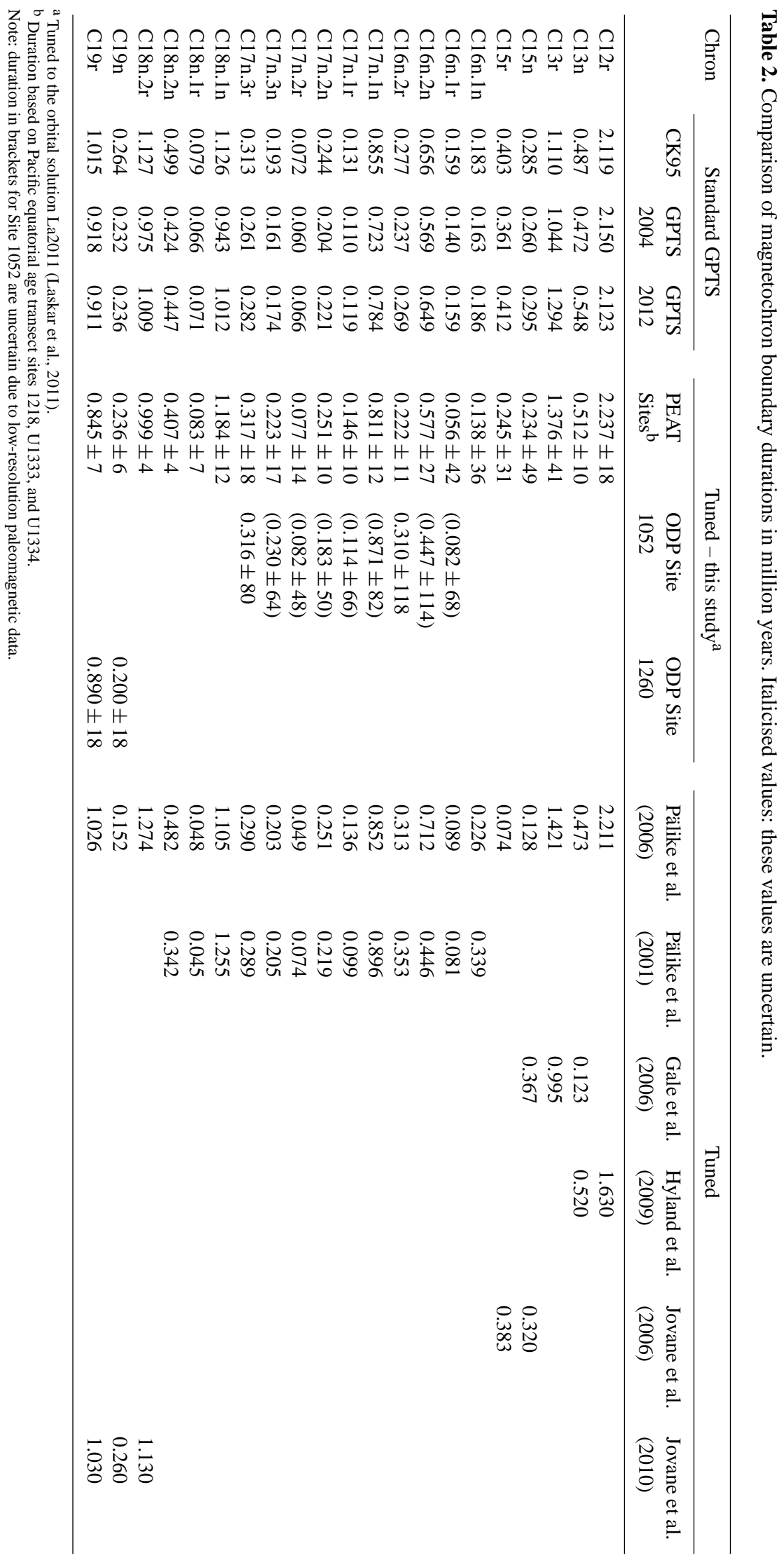


because it uses a relatively young age of $45.60 \pm 0.38 \mathrm{Ma}$ for an ash layer in C21n compared to CK95 (Westerhold and Röhl, 2009) and GPTS2012.

The most obvious differences in the age estimates are observed in the late Eocene, namely for Chron C15 and the younger part of Chron C16. The new GPTS as well as Pälike et al. (2006) gives durations for both Chrons C15r and $\mathrm{C} 16 \mathrm{n} .1 \mathrm{r}$ that are shorter than other timescales and gives durations for Chron $\mathrm{C} 13 \mathrm{r}$ that are longer than other timescales. Pälike et al. (2012) suggested this was related to highly dynamic variations in the CCD in the equatorial Pacific. Other suitable sites with sufficient high-quality magneto- and cyclostratigraphy to decipher this part of the timescale fully are not yet available from the deep sea. Two marine sections and one continental section with established magneto- and cyclostratigraphies are, however, already available for Chron C13r: the Solent Group from the Isle of Wight in the UK (Gale et al., 2006), the Massignano GSSP section in central Italy (Premoli Silva and Jenkins, 1993; Jovane et al., 2006, Brown et al., 2009), and the lacustrine records from the Xining Basin on the Tibetan Plateau (Dupont-Nivet et al., 2007; Xiao et al., 2010). Both the Solent Group record (Gale et al., 2006) and the Massignano section (Jovane et al., 2006, Brown et al., 2009) suggest that Chron C13r lasted the equivalent of 2.5 long eccentricity cycles or $\sim 1000 \mathrm{kyr}$. Obliquity-driven cyclicity in physical properties from the Xining basin record imply an even shorter duration, on the order of 800-900 kyr, of Chron C13r (Xiao et al., 2010). This would require that PEAT records overestimate the duration of Chron C13r by $\sim 400 \mathrm{kyr}$ or one long eccentricity cycle. Alternatively, the Solent Group record may be condensed or incomplete in $\mathrm{C} 13 \mathrm{n}$ and around the $\mathrm{C} 13 \mathrm{r}-\mathrm{C} 15 \mathrm{n}$ boundary. A hint for this scenario could be a hiatus in Chron C13n and the fact that the Chron $\mathrm{C} 13 \mathrm{r}-\mathrm{C} 15 \mathrm{n}$ boundary is characterized only by an incomplete illitic clay cycle.

At the Massignano section uncertainties may lie in the array of estimated 10-12 m length for Chron C13r (Lowrie and Lanci, 1994). Based on average sedimentation rates of $0.7 \mathrm{~cm} \mathrm{kyr}^{-1}$ the dominant cycles in the Massignano section with lengths of 32,72 , and $284 \mathrm{~cm}$ relate to periods of 45, 102, and $405 \mathrm{kyr}$, respectively (Jovane et al., 2006). These periods and their frequency ratio are diagnostic of obliquity and eccentricity related cycles. However, this basic calculation does not account for the range in thickness of Chron C13r (10-12 m). Applying $1376 \mathrm{kyr}$ for the duration of Chron C13r (Table 2), sedimentation rates at Massignano would then range between $0.73 \mathrm{~cm} \mathrm{kyr}^{-1}(10 \mathrm{~m}$ thickness of Chron C13r) and $0.87 \mathrm{~cm} \mathrm{kyr}^{-1}(12 \mathrm{~m}$ thickness of Chron C13r). The cyclicity in the Massignano section and the $1376 \mathrm{kyr}$ duration for Chron $\mathrm{C} 13 \mathrm{r}$ are most consistent with the $10 \mathrm{~m}$ estimate of thickness for Chron C13r in the Massignano section. But a duration of $1376 \mathrm{kyr}$ for $\mathrm{C} 13 \mathrm{r}$ is not consistent with the interpretation that lacustrine records from the Xining Basin (Xiao et al., 2010) are obliquity driven. Chron $\mathrm{C} 15 \mathrm{n}$ and $\mathrm{C} 15 \mathrm{r}$ are shorter in the PEAT records than estimated for the Massignano section (Jovane et al., 2006; Brown et al., 2009). Sedimentation rates increase during Chrons $\mathrm{C} 15$ and $\mathrm{C} 16$ in the PEAT record (Fig. 8). In the carbonate record of interval C16n.1n to early Chron $\mathrm{C} 13 \mathrm{r}$ at Massignano a temporary shift from obliquity to $26-30 \mathrm{kyr}$ cycles occurs and is interpreted as a possible feedback to impact/comet shower related climate change (Brown et al., 2009). If the calculated sedimentation rates of $\sim 0.8 \mathrm{~cm} \mathrm{kyr}^{-1}$ is applied, however, the observed 26-30 kyr cycles in the interval from 5.6 to $13 \mathrm{~m}$ at Massignano (Brown et al., 2009) becomes $\sim 20 \mathrm{kyr}$ cycles. Although the thickness of Chron $\mathrm{C} 15 \mathrm{r}$ in the Massignano section is not unambiguous (Lowrie and Lanci, 1994), this interpretation indicates that the duration of Chron $\mathrm{C} 15 \mathrm{r}$ should be about a third shorter than the $383 \mathrm{kyr}$ of Jovane et al. (2006). If correct, the duration of $\mathrm{C} 15 \mathrm{r}$ is $\sim 250 \mathrm{kyr}-$ as observed at the PEAT sites (214-286 kyr). The $74 \mathrm{kyr}$ estimate of Pälike et al. (2006) is far too short (Westerhold et al., 2012a) as indicated by the unusual sedimentation rate increase in $\mathrm{C} 15$ (Supplement Fig. S11). The durations for Chron C16n.1n and C16n.1r are not as well resolved in the PEAT record as in other records studied.

Ages and durations of magnetochrons Chron C16n.2n through $\mathrm{C} 17 \mathrm{n} .3 \mathrm{r}$ are well constrained by a combination of the PEAT records and Site 1052 results. Due to the coarser sampling interval the error for the magnetic reversal boundaries obtained from Site 1052 is relatively large and can only provide good estimates for $\mathrm{C} 16 n .2 \mathrm{n}$, top $\mathrm{C} 17 \mathrm{n}$. $1 \mathrm{n}$, base C17n.3n, and top C18n.1n. Pälike et al. (2001) used the La1993 (Laskar et al., 1993) solution for orbital calibration and therefore the tuned ages for Site 1052 differ by $\sim 100 \mathrm{kyr}$ compared to those applying the now available La2011 solution. The new estimates are close to CK95 and Pälike et al. (2006) ages, but older than GPTS2004 and younger than GPTS2012. For Chrons C18 and C19, integration of the PEAT records with records containing well-pronounced cyclicity from Sites 1172 and 1260 allows a very accurate age calibration from Chron C18 to the top of Chron C20n. Due to uncertainty in the 1172 magnetic stratigraphy the exact duration of C18n. $1 \mathrm{n}$ and $\mathrm{C} 18 \mathrm{n} .2 \mathrm{n}$ is uncertain, but a good approximation is available from the PEAT magnetostratigraphy. The ages from CK95 become increasingly older and those from GPTS2004 increasingly younger in the C18$\mathrm{C} 20 \mathrm{n}$ interval. The difference originates from a relatively old (young) age for the ash in C21n.33 (33\% down in Chron C21n) of $46.8 \mathrm{Ma}(45.6 \mathrm{Ma})$ in CK95 (GPTS2004). Therefore, the GPTS2012 calibration omitted this tie point and alternatively used the ${ }^{40} \mathrm{Ar} /{ }^{39} \mathrm{Ar}$ age of $43.35 \pm 0.5 \mathrm{Ma}$ for the Mission Valley Ash (California, USA) near the base of C20n (Prothero and Emry, 1996; Walsh et al., 1996; Smith et al., 2010) (Fig. 9). According to the new tuned GPTS ages the age of the Mission Valley Ash date is about $300 \mathrm{kyr}$ too old. One explanation could be that the GPTS2012 applied an age of $28.201 \mathrm{Ma}$ (Kuiper et al., 2008) for the FCT ${ }^{40} \mathrm{Ar} /{ }^{39} \mathrm{Ar}$ dating standard. 


\subsection{Paleoceanographic implications}

Two prominent features in the PEAT records and the new astronomical timescale need to be briefly discussed. One is the change in phase relationship between stable carbon isotope and XRF core scanning data in relation to the short and long eccentricity cycle (see Fig. 10 and Supplement Fig. S12). From $43 \mathrm{Ma}$, where our study starts, to $40.5 \mathrm{Ma}$ the records are in-phase with low $\mathrm{Fe}$ and $\mathrm{Si}$, and with high $\mathrm{Ca}$ corresponding to lower $\delta^{13} \mathrm{C}$ values. The phase relation switches around $40.5 \mathrm{Ma}$ to an anti-phase mode at all three sites and this pattern remains until $\sim 36 \mathrm{Ma}$. Due to strong dissolution no distinct relation is observable between 36 and $35 \mathrm{Ma}$. After $\sim 35 \mathrm{Ma}$ the records are again in phase. The switch in phase relation of isotopes vs. carbonate content is similar to the shift from the Atlantic-type (high carbonate in interglacials) to Pacific-type (high carbonate in glacials) carbonate stratigraphy observed during the earliest Gauss Magnetic Chron (3.18-3.41 Ma) in equatorial Pacific sediments (Moore Jr. et al., 1982; Dunn, 1982), close to the onset of northern hemisphere glaciation. The shift in phase relation prior to the EOT could be related to a change in the deep and intermediate water circulation (Katz et al., 2011). This reorganization in ocean circulation is also expressed in the response of the equatorial Pacific to orbital forcing and probably also affected the distribution of nutrients.

The other important feature is the occurrence of an obliquity-dominated cyclicity coinciding with the 2.4 myr eccentricity minima at $35.5 \mathrm{Ma}$ (Site 1052; Pälike et al., 2001; Fig. 6, 405 cycle 88), at 38.3 Ma and 40.1 Ma (both Site 1172, Fig. 7, cycles 95 and 99/100). Prominent obliquity cycles are not present in the PEAT records probably due to their low-latitude setting. At both intervals around 40.1 and 38.3 Ma relatively high amounts of ice-rafted debris (IRD) have been reported from the Greenland Sea Site 913 (Eldrett et al., 2007; Tripati et al., 2008) with an age model approach based on CK95, which is therefore chronologically comparable to the PEAT record. At $35.5 \mathrm{Ma}$ an increase in IRD is reported from the same high latitude site (Eldrett et al., 2007) in Chron C15r, coincident with a cooling shift observed at the Southern Ocean Site 689B (Vonhof et al., 2000) and a major sea level fall (Peters et al., 2010). From the new stratigraphic framework defined for the PEAT record, we would hypothesize that the cooling as reflected by the higher amount of IRD in the Greenland Sea might be fostered by the 2.4 myr eccentricity minima at $35.5,38.3$, and $40.1 \mathrm{Ma}$ (405 kyr cycles 88 , 95 , and 100). The occurrence of contemporaneous obliquity cycles at Sites 1172 and 1052 suggests that to some extent high-latitude processes driven by orbital obliquity strongly influenced ocean circulation during 2.4 myr eccentricity minima. Temperatures at high latitudes cool enough to form ice in the Arctic already occurred at 47-46 Ma ago (Stickley et al., 2009; St. John et al., 2008). With decreasing atmospheric $\mathrm{CO}_{2}$ (Pearson and Palmer, 2000; DeConto and Pollard, 2003; Pollard and DeConto, 2005) in an environment and aftermath

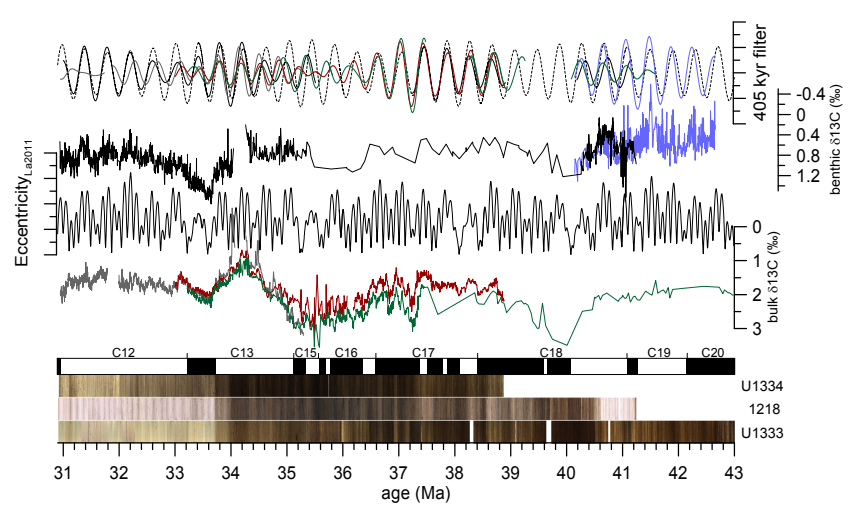

Figure 10. Tuned bulk and benthic stable carbon isotope data plotted against La2011 orbital solution for eccentricity (Laskar et al., 2011b). Bulk data: 1218 (gray; Pälike et al., 2006), U1333 (green; this paper; Wilson et al., unpublished; Leon-Rodriquez and Dickens, 2013), U1334 (red; this paper; Wilson et al., unpublished). Benthic data: 1218 (black; Lear et al., 2004; Coxall et al., 2005; Tripati et al., 2005; Coxall and Wilson, 2011), 1260 (blue; Edgar et al., 2007). Long eccentricity ( $405 \mathrm{kyr}$ ) band pass filters of the detrended, tuned records are plotted on top La2011 (dash line). Magnetostratigraphy as provided in Table 1 and combined core images from Site U1333, U1334, and 1218 for illustration.

of gateway evolution (Bijl et al., 2013), orbital forcing might have fostered ephemeral ice buildup on Antarctica causing a sea level fall (Peters et al., 2010) and seasonal sea-ice formation in the Arctic. The data presented here from PEAT so far support the suggestion that high-latitude processes had little effect in equatorial regions (Pearson et al., 2007) during the late Eocene.

\section{Summary and conclusions}

A new stratigraphic framework has been assembled based on the identification of the stable long eccentricity cycle for the middle to late Eocene into the early Oligocene (43-31 Ma) across the Eocene-Oligocene Transition. The here presented cyclostratigraphies are based on integrated high-resolution bulk and benthic stable isotope data, calibrated XRF core scanning data and magnetostratigraphy from Pacific Equatorial Sites 1218 (ODP Leg 199), U1333, U1334 (IODP Expeditions 320/321), Atlantic Sites 1052 (ODP Leg 171), and 1260 (ODP Leg 207) as well as Tasman Sea Site 1172 (ODP Leg 189). The records were tuned to the La2011 orbital solution to establish a robust absolute age model. The new chronology provides an astronomically calibrated age model for the PEAT sites and accurate estimates for the geomagnetic polarity timescale (GPTS) covering Chrons C12n$\mathrm{C} 20$ n that are calibrated to the short eccentricity cycle level. However, for now the age model is still ambiguous for Chron $\mathrm{C} 15 \mathrm{n}$ to the top of $\mathrm{C} 16 \mathrm{n}$ due to the highly dynamic variability of the carbonate compensation depth in the equatorial 
Pacific. The age estimates support the CK95 calibration, are discordant with the GPTS2004 calibration, and reveal a systematic offset of about $>300 \mathrm{kyr}$ relative to GPTS2012 for late Eocene reversals from Chron $\mathrm{C} 15 \mathrm{r}-\mathrm{C} 17 \mathrm{r}$. The chronology of changes in the phase relationship in PEAT records between XRF core scanning data and stable carbon isotope data suggests a close linkage to changes in overall deep-ocean circulation at 40.5 and 35-36 Ma. The synopsis of the records utilized for the cyclostratigraphy reveals strong obliquity related cycles in middle to high-latitude sites $(1052,1171)$ during 2.4 myr eccentricity minima at $35.5,38.3$, and $40.1 \mathrm{Ma}$.

\section{The Supplement related to this article is available online at doi:10.5194/cp-10-955-2014-supplement.}

Acknowledgements. This research used samples and/or data provided by the Ocean Drilling Program (ODP) and Integrated Ocean Drilling Program (IODP). Data have been acquired in the XRF Core Scanner Lab at the MARUM - Center for Marine Environmental Sciences, University of Bremen, Germany. We thank Monika Segl and her team (MARUM) for stable isotope analysis. We thank Jan Backman, an anonymous reviewer, and Editor Andrea Dutton for thorough reviews and comments in the discussion phase improving the manuscript. Funding for this research was provided by the Deutsche Forschungsgemeinschaft (DFG), NERC, and the National Science Foundation (Grant NSF OCE-0961412). We are indebted to V. Lukies (MARUM) for assisting in XRF core scanning, and the staff at BCR and GCR for core handling. The complete data set presented in this paper is available online in the WDC-MARE PANGAEA database under www.pangaea.de.

Edited by: A. Dutton

\section{References}

Bijl, P. K., Houben, A. J. P., Schouten, S., Bohaty, S. M., Sluijs, A., Reichart, G.-J., Sinninghe Damste, J. S., and Brinkhuis, H.: Transient Middle Eocene Atmospheric $\mathrm{CO}_{2}$ and Temperature Variations, Science, 330, 819-821, doi:10.1126/science.1193654, 2010.

Bijl, P. K., Bendle, J. A. P., Bohaty, S. M., Pross, J., Schouten, S., Tauxe, L., Stickley, C. E., McKay, R. M., Röhl, U., Olney, M., Sluijs, A., Escutia, C., Brinkhuis, H., and Scientists, E.: Eocene cooling linked to early flow across the Tasmanian Gateway, P. Natl. Acad. Sci. USA, 110, 9645-9650, doi:10.1073/pnas.1220872110, 2013.

Bohaty, S. and Zachos, J. C.: Significant Southern Ocean warming event in the late middle Eocene, Geology, 31, 1017-1020, 2003.

Bohaty, S. M., Zachos, J. C., Florindo, F., and Delaney, M. L.: Coupled greenhouse warming and deep-sea acidification in the middle Eocene, Paleoceanography, 24, PA2207, doi:10.1029/2008pa001676, 2009.
Bohaty, S. M., Zachos, J. C., and Delaney, M. L.: Foraminiferal $\mathrm{Mg} / \mathrm{Ca}$ evidence for Southern Ocean cooling across the EoceneOligocene transition, Earth Planet. Sc. Lett., 317-318, 251-261, doi:10.1016/j.eps1.2011.11.037, 2012.

Brown, R. E., Koeberl, C., Montanari, A., and Bice, D. M.: Evidence for a change in Milankovitch forcing caused by extraterrestrial events at Massignano, Italy, Eocene-Oligocene boundary GSSP, in: The Late Eocene Earth - Hothouse, Icehouse and Impacts, edited by: Koeberl, C., and Montanari, A., Geol. S. Am. S., 452, 119-137, doi:10.1130/2009.2452(08), 2009.

Burgess, C. E., Pearson, P. N., Lear, C. H., Morgans, H. E. G., Handley, L., Pancost, R. D., and Schouten, S.: Middle Eocene climate cyclicity in the southern Pacific: Implications for global ice volume, Geology, 36, 651-654, 2008.

Cande, S. C. and Kent, D. V.: Revised calibration of the geomagnetic polarity timescale for the Late Cretaceous and Cenozoic, J. Geophys. Res., 100, 6093-6095, 1995.

Coxall, H. K. and Wilson, P. A.: Early Oligocene glaciation and productivity in the eastern equatorial Pacific: Insights into global carbon cycling, Paleoceanography, 26, PA2221, doi:10.1029/2010pa002021, 2011.

Coxall, H. K., Wilson, P. A., Pälike, H., Lear, C. H., and Backman, J.: Rapid stepwise onset of Antarctic glaciation and deeper calcite compensation in the Pacific Ocean, Nature, 433, 53-57, doi:10.1038/nature03135, 2005.

DeConto, R. M. and Pollard, D.: Rapid Cenozoic glaciation of Antarctica induced by declining atmospheric $\mathrm{CO}_{2}$, Nature, 421, 245-249, doi:10.1038/nature01290, 2003.

DeConto, R. M., Pollard, D., Wilson, P. A., Pälike, H., Lear, C. H., and Pagani, M.: Thresholds for Cenozoic bipolar glaciation, Nature, 455, 652-656, doi:10.1038/nature07337, 2008.

Dunn, D. A.: Change from "Atlantic-type" to "Pacific-type" carbonate stratigraphy in the middle Pliocene Equatorial Pacific Ocean, Mar. Geol., 50, 41-59, doi:10.1016/0025-3227(82)90060-3, 1982.

Dupont-Nivet, G., Krijgsman, W., Langereis, C. G., Abels, H. A., Dai, S., and Fang, X.: Tibetan plateau aridification linked to global cooling at the Eocene-Oligocene transition, Nature, 445, 635-638, 2007.

Edgar, K. M., Wilson, P. A., Sexton, P. F., and Suganuma, Y.: No extreme bipolar glaciation during the main Eocene calcite compensation shift, Nature, 448, 908-911, doi:10.1038/nature06053, 2007.

Edgar, K. M., Wilson, P. A., Sexton, P. F., Gibbs, S. J., Roberts, A. P., and Norris, R. D.: New biostratigraphic, magnetostratigraphic and isotopic insights into the Middle Eocene Climatic Optimum in low latitudes, Palaeogeogr. Palaeocl., 297, 670-682, doi:10.1016/j.palaeo.2010.09.016, 2010.

Ehrmann, W. U. and Mackensen, A.: Sedimentological evidence for the formation of an East Antarctic ice sheet in Eocene/Oligocene time, Palaeogeogr. Palaeocl., 93, 85-112, doi:10.1016/00310182(92)90185-8, 1992.

Eldrett, J. S., Harding, I. C., Wilson, P. A., Butler, E., and Roberts, A. P.: Continental ice in Greenland during the Eocene and Oligocene, Nature, 446, 176-179, 2007.

Fuller, M. and Touchard, Y.: On the Magnetostratigraphy of the East Tasman Plateau, Timing of the Opening of the Tasmanian Gateway and Paleoenvironmental Changes, in: The Cenozoic Southern Ocean: Tectonics, Sedimentation and Climate Change 
between Australia and Antarctica, edited by: Exon, N. F., Kennett, J. P., and Malone, M. J., Am. Geophys. Union, Geophys. Monogr., 63-78, 2004.

Gale, A. S., Huggett, J. M., Pälike, H., Laurie, E., Hailwood, E. A., and Hardenbol, J.: Correlation of Eocene-Oligocene marine and continental records: orbital cyclicity, magnetostratigraphy and sequence stratigraphy of the Solent Group, Isle of Wight, UK, J. Geol. Soc. London, 163, 401-415, doi:10.1144/0016-764903$175,2006$.

Grazzini, C. V. and Oberhaensli, H.: Isotopic Events at the Eocene/Oligocene Transition. A Review, Developments in Palaeontology and Stratigraphy, 311-329, doi:10.1016/S09205446(08)70136-5, 1986.

Guidry, E. P., Richter, C., Acton, G. D., Channell, J. E. T., Evans, H. F., Ohneiser, C., Yamamoto, Y., and Yamazaki, T.: OligoceneMiocene magnetostratigraphy of deep-sea sediments from the Equatorial Pacific (IODP Site U1333), Geological Society, London, Special Publications, 373, 13-27, doi:10.1144/SP373.7, 2013.

Hay, W. W., DeConto, R., Wold, C. N., Wilson, K. M., Voigt, S., Schulz, M., Wold-Rossby, A., Dullo, W.-C., Ronov, A. B., Balukhovsky, A. N., and Soeding, E.: Alternative Global Cretaceous Paleogeography, in: The Evolution of Cretaceous Ocean/Climate Systems, edited by: Barrera, E. and Johnson, C., Geological Society of America Special Paper, 1-47, 1999.

Hilgen, F. J. and Kuiper, K. F.: A critical evaluation of the numerical age of the Eocene-Oligocene boundary, in: The Late Eocene Earth - Hothouse, Icehouse, and Impacts: Geological Society of America Special Paper, edited by: Koeberl, C. and Montanari, A., Geol. S. Am. S., 452, 139-148, doi:10.1130/2009.2452(09), 2009.

Hinnov, L. A. and Hilgen, F. J.: Cyclostratigraphy and Astrochronology, in: The Geological Timescale 2012, edited by: Gradstein, F. M., Ogg, J. G., Schmitz, M. D., and Ogg, G. M., Elsevier, 63-83, doi:10.1016/B978-0-444-59425-9.00004-4, 2012.

IODP (Integrated Ocean Drilling Program): IODP Depth Scales Terminology, available at: www.iodp.org/doc_download/ 3171-iodpdepthscaleterminologyv2, last access: 12 May 2014, 2011.

Jovane, L., Florindo, F., Sprovieri, M., and Pälike, H.: Astronomic calibration of the late Eocene/early Oligocene Massignano section (central Italy), Geochem. Geophy. Geosy., 7, Q07012, doi:10.1029/2005GC001195, 2006.

Katz, M. E., Cramer, B. S., Toggweiler, J. R., Esmay, G., Liu, C., Miller, K. G., Rosenthal, Y., Wade, B. S., and Wright, J. D.: Impact of Antarctic Circumpolar Current Development on Late Paleogene Ocean Structure, Science, 332, 1076-1079, doi:10.1126/science.1202122, 2011.

Kirschvink, J. L.: The least-squares line and plane and the analysis of palaeomagnetic data, Geophys. J. Roy. Astr. S., 62, 699-718, 1980.

Koeberl, C. and Montanari, A.: The Late Eocene Earth - Hothouse, Icehouse and Impacts, Geol. S. Am. S., 322 pp., 2009.

Kuiper, K. F., Deino, A., Hilgen, F. J., Krijgsman, W., Renne, P. R., and Wijbrans, J. R.: Synchronizing Rock Clocks of Earth History, Science, 320, 500-504, doi:10.1126/science.1154339, 2008.

Kuroda, J. and Westerhold, T.:: Data report: volcanic glass shards from the Eocene-Oligocene transition interval at Site U1333, in: Proceedings of the Integrated Ocean Drilling Program, 320/321, edited by: Pälike, H., Lyle, M., Nishi, H., Raffi, I., Gamage, K., Klaus, A., and the Expedition 320/321 Scientists, doi:10.2204/iodp.proc.320321.211.2013, 2013.

Lanci, L., Pares, J. M., Channell, J. E. T., and Kent, D. V.: Miocene magnetostratigraphy from Equatorial Pacific sediments (ODP Site 1218, Leg 199), Earth Planet. Sc. Lett., 226, 207-224, doi:10.1016/j.eps1.2004.07.025, 2004.

Lanci, L., Parés, J. M., Channell, J. E. T., and Kent, D. V.: Oligocene magnetostratigraphy from Equatorial Pacific sediments (ODP Sites 1218 and 1219, Leg 199), Earth Planet. Sc. Lett., 237, 617634, doi:10.1016/j.eps1.2005.07.004, 2005.

Laskar, J., Joutel, F., and Boudin, F.: Orbital, precessional, and insolation quantities for the earth from $-20 \mathrm{Myr}$ to $+10 \mathrm{Myr}$, Astron. Astrophys., 270, 522-533, 1993.

Laskar, J., Robutel, P., Joutel, F., Gastineau, M., Correia, A., and Levrard, B.: A long-term numerical solution for the insolation quantities of the Earth, Astron. Astrophys., 428, 261-285, doi:10.1051/0004-6361:20041335, 2004.

Laskar, J., Fienga, A., Gastineau, M., and Manche, H.: La2010: a new orbital solution for the long-term motion of the Earth, Astron. Astrophys., 532, A89, doi:10.1051/0004-6361/201116836, 2011a.

Laskar, J., Gastineau, M., Delisle, J. B., Farrés, A., and Fienga, A.: Strong chaos induced by close encounters with Ceres and Vesta, Astron. Astrophys., 532, L4, doi:10.1051/00046361/201117504, 2011 b.

Lear, C. H., Rosenthal, Y., Coxall, H. K., and Wilson, P. A.: Late Eocene to early Miocene ice sheet dynamics and the global carbon cycle, Paleoceanography, 19, PA4015, doi:10.1029/2004PA001039, 2004.

Lear, C. H., Bailey, T. R., Pearson, P. N., Coxall, H. K., and Rosenthal, Y.: Cooling and ice growth across the Eocene-Oligocene transition, Geology, 36, 251-254, 2008.

Leon-Rodriguez, L. and Dickens, G. R.: Data report: stable isotope composition of Eocene bulk carbonate at Sites U1331, U1332, and U1333, in: Proceedings of the Integrated Ocean Drilling Program, 320/321, edited by: Pälike, H., Lyle, M., Nishi, H., Raffi, I., Gamage, K., Klaus, A., and and the Expedition 320/321 Scientists, doi:10.2204/iodp.proc.320321.208.2013, 2013.

Liu, Z., Pagani, M., Zinniker, D., DeConto, R., Huber, M., Brinkhuis, H., Shah, S. R., Leckie, R. M., and Pearson, A.: Global Cooling During the Eocene-Oligocene Climate Transition, Science, 323, 1187-1190, doi:10.1126/science.1166368, 2009.

Lourens, L. J., Hilgen, F. J., Laskar, J., Shackleton, N. J., and Wilson, D.: The Neogene Period, in: A Geological Timescale 2004, edited by: Gradstein, F., Ogg, J., and Smith, A., 409-440, Cambridge University Press, Cambridge, UK, doi:10.1017/CBO9780511536045.022, 2004.

Lourens, L. J., Sluijs, A., Kroon, D., Zachos, J.'C., Thomas, E., Röhl, U., Bowles, J., and Raffi, I.: Astronomical pacing of late Palaeocene to early Eocene global warming events, Nature, 435, 1083-1087, doi:10.1038/nature03814, 2005.

Lowrie, W. and Lanci, L.: Magnetostratigraphy of EoceneOligocene boundary sections in Italy: No evidence for short subchrons within chrons 12R and 13R, Earth Planet. Sc. Lett., 126, 247-258, doi:10.1016/0012-821X(94)90110-4, 1994. 
Luterbacher, H. P., Ali, J. R., Brinkhuis, H., Gradstein, F. M., Hooker, J. J., Monechi, S., Ogg, J. G., Powell, J., Röhl, U., Sanfilippo, A., Schmitz, B.: The Paleogene Period, in: A Geological Timescale 2004, edited by: Gradstein, F., Ogg, J., and Smith, A., Cambridge University Press, 20, 384-408, doi:10.1017/CBO9780511536045.021, 2004.

Lyle, M., Wilson, P. A., Janecek, T. R., et al.: Initial Reports volume citation, in: Proceedings of the Ocean Drilling Program Initial Reports, Leg 199: College Station, TX (Ocean Drilling Program), USA, 2002.

Lyle, M., Olivarez Lyle, A., Backman, J., and Tripati, A.: Biogenic sedimentation in the Eocene equatorial Pacific - the stuttering greenhouse and Eocene carbonate compensation depth, in: Proc. ODP, Sci. Results, 199: College Station, TX (Ocean Drilling Program), edited by: Wilson, P. A., Lyle, M., and Firth, J. V., 1-35, doi:10.2973/odp.proc.sr.199.219.2005, 2005.

Lyle, M., Olivarez Lyle, A., Gorgas, T., Holbourn, A., Westerhold, T., Hathorne, E., Kimoto, K., and Yamamoto, S.: Data report: raw and normalized elemental data along the Site U1338 splice from X-ray fluorescence scanning, in: Proc. IODP, 320/321: Tokyo (Integrated Ocean Drilling Program Management International, Inc.), edited by: Pälike, H., Lyle, M., Nishi, H., Raffi, I., Gamage, K., Klaus, A., and and the Expedition 320/321 Scientists, doi:10.2204/iodp.proc.320321.203.2012, 2012.

Miller, K. G., Wright, J. D., and Fairbanks, R. G.: Unlocking the icehouse: Oligocene-miocene oxygen isotope, eustacy, and margin erosion, J. Geophys. Res., 96, 6829-6848, 1991.

Moore, T. C. and Kamikuri, S.: Data report: radiolarian stratigraphy across the Eocene/Oligocene boundary in the equatorial Pacific, Sites 1218, U1333, and U1334, in: Proc. IODP, 320/321: Tokyo (Integrated Ocean Drilling Program Management International, Inc.), edited by: Pälike, H., Lyle, M., Nishi, H., Raffi, I., Gamage, K., Klaus, A., and and the Expedition 320/321 Scientists, doi:10.2204/iodp.proc.320321.204.2012, 2012.

Moore Jr., T. C.: Erosion and reworking of Pacific sediments near the Eocene-Oligocene boundary, Paleoceanography, 28, 263273, doi:10.1002/palo.20027, 2013.

Moore Jr., T. C., Pisias, N. G., and Dunn, D. A.: Carbonate time series of the Quaternary and Late Miocene sediments in the Pacific Ocean: A spectral comparison, Mar. Geol.y, 46, 217-233, 1982.

ODSN (Ocean Drilling Stratigraphic Network), available at: http: //www.odsn.de, last access: 12 May 2014, 2011.

Ogg, J. G.: Geomagnetic Polarity time scale, in: The Geological Timescale 2012, edited by: Gradstein, F., Ogg, J., Schmitz, M. D., and Ogg, G. M., Elsevier, 85-114, 2012.

Ogg, J. G. and Bardot, L.,: Aptian through Eocene magnetostratigraphic correlation of the Blake Nose Transect (Leg 171B), Florida continental margin, in: Proceedings of the Ocean Drilling Program, edited by: Kroon, D., Norris, R. D., and Klaus, A., Scientific Results Volume 171B, 1-58, doi:10.2973/odp.proc.sr.171b.104.2001, 2001.

Ogg, J. G. and Smith, A. G.: The geomagnetic polarity time scale, in: A Geological Timescale 2004, edited by: Gradstein, F., Ogg, J., and Smith, A., Cambridge University Press, Cambridge University Press, Cambridge, UK, 63-86, 2004.

Pälike, H., Shackleton, N. J., and Röhl, U.: Astronomical forcing in Late Eocene marine sediments, Earth Planet. Sc. Lett., 193, 589-602, 2001.
Pälike, H., Moore, T., Backman, J., Raffi, I., Lanci, L., Parés, J. M., and Janecek, T.: Integrated stratigraphic correlation and improved composite depth scales for ODP Sites 1218 and 1219, in: Proceedings of the Ocean Drilling Program, edited by: Wilson, P. A., Lyle, M., and Firth, J. V., Scientific Results Volume 199, 1-41, doi:10.2973/odp.proc.sr.199.213.2005, 2005.

Pälike, H., Norris, R. D., Herrle, J. O., Wilson, P. A., Coxall, H. K., Lear, C. H., Shackleton, N. J., Tripati, A. K., and Wade, B. S.: The Heartbeat of the Oligocene Climate System, Science, 314, 1894-1898, doi:10.1126/science.1133822, 2006.

Pälikelike, H., Nishi, H., Lyle, M., Raffi, I., Gamage, K., Klaus, A., and the Expedition 320/321 Scientists: Proc. IODP, 320/321: Tokyo (Integrated Ocean Drilling Program Management International, Inc.), doi:10.2204/iodp.proc.320321, 2010.

Pälike, H., Lyle, M. W., Nishi, H., Raffi, I., Ridgwell, A., Gamage, K., Klaus, A., Acton, G., Anderson, L., Backman, J., Baldauf, J., Beltran, C., Bohaty, S. M., Bown, P., Busch, W., Channell, J. E. T., Chun, C. O. J., Delaney, M., Dewangan, P., Dunkley Jones, T., Edgar, K. M., Evans, H., Fitch, P., Foster, G. L., Gussone, N., Hasegawa, H., Hathorne, E. C., Hayashi, H., Herrle, J. O., Holbourn, A., Hovan, S., Hyeong, K., Iijima, K., Ito, T., Kamikuri, S.-I., Kimoto, K., Kuroda, J., Leon-Rodriguez, L., Malinverno, A., Moore Jr, T. C., Murphy, B. H., Murphy, D. P., Nakamura, H., Ogane, K., Ohneiser, C., Richter, C., Robinson, R., Rohling, E. J., Romero, O., Sawada, K., Scher, H., Schneider, L., Sluijs, A., Takata, H., Tian, J., Tsujimoto, A., Wade, B. S., Westerhold, T., Wilkens, R., Williams, T., Wilson, P. A., Yamamoto, Y., Yamamoto, S., Yamazaki, T., and Zeebe, R. E.: A Cenozoic record of the equatorial Pacific carbonate compensation depth, Nature, 488, 609-614, doi:10.1038/nature11360, 2012.

Pearson, P. N. and Palmer, M. R.: Atmospheric carbon dioxide concentrations over the past 60 million years, Nature, 406, 695-699, doi:10.1038/35021000, 2000.

Pearson, P. N., van Dongen, B. E., Nicholas, C. J., Pancost, R. D., Schouten, S., Singano, J. M., and Wade, B. S.: Stable warm tropical climate through the Eocene Epoch, Geology, 35, 211-214, doi:10.1130/g23175a.1, 2007.

Pearson, P. N., McMillan, I., Wade, B., Jones, T., Coxall, H., Bown, P., Lear, C.: Extinction and environmental change across the Eocene-Oligocene boundary in Tanzania, Geology, 36, 179-182, doi:10.1130/G24308A.1, 2008.

Peters, S. E., Carlson, A. E., Kelly, D. C., and Gingerich, P. D.: Large-scale glaciation and deglaciation of Antarctica during the Late Eocene, Geology, 38, 723-726, doi:10.1130/g31068.1, 2010.

Pollard, D. and DeConto, R. M.: Hysteresis in Cenozoic Antarctic ice-sheet variations, Global Planet. Change, 45, 9-21, doi:10.1016/j.gloplacha.2004.09.011, 2005

Premoli Silva, I. and Jenkins, G. D.: Decision on the EoceneOligocene boundary stratotype, Episodes, 16, 379-382, 1993.

Prentice, M. L. and Matthews, R. K.: Cenozoic icevolume history: Development of a composite oxygen isotope record, Geology, 16, 963-966, doi:10.1130/00917613(1988)016<0963:civhdo>2.3.co;2, 1988.

Prothero, D. R. and Emry, R. J.: The Terrestrial Eocene-Oligocene Transition in North America, Cambridge University Press, Cambridge, 1996. 
Prothero, D. R., Ivany, L. C., and Nesbitt, E. A.: From greenhouse to icehouse: The marine Eocene-Oligocene transition, Columbia University Press, New York, 2003.

Röhl, U. and Abrams, L. J.: High-Resolution, Downhole and NonDestructive Core Measurements from Sites 999 and 1001 in the Caribbean Sea: Application to the Late Paleocene Thermal Maximum, in: Proceedings of the Ocean Drilling Program, edited by: Leckie, R. M., Sigurdsson, H., Acton, G. D., and Draper, G., Scientific Results, College Station, TX (Ocean Drilling Program), 165, 191-203, doi:10.2973/odp.proc.sr.165.009.2000, 2000.

Röhl, U., Wefer, G., Brinkhuis, H., Stickley, C. E., Fuller, M., Schellenberg, S. A., and Williams, G. L.: Sea level and astronomically induced environmental changes in middle and late sediments from the East Tasman Plateau, in: The Cenozoic Southern Ocean: Tectonics, Sedimentation and Climate Change between Australia and Antarctica, edited by: Exon, N. F., Kennett, J. P., and Malone, M. J., American Geophysical Union (AGU), Geoph. Monog. Series, 151, 113-126, 2004.

Röhl, U., Westerhold, T., Bralower, T. J., and Zachos, J. C.: On the duration of the Paleocene-Eocene thermal maximum (PETM), Geochem. Geophy. Geosy., 8, Q12002, doi:10.1029/2007GC001784, 2007.

Shackleton, N. J. and Kennett, J. P.: Paleotemperature History Of The Cenozoic and The Initiation of Antarctic Glaciation: Oxygen and Carbon Isotope analyses in DSDP Sites 277, 279, and 281, in: Deep Sea Drilling Project (DSDP), Volume XXIX, edited by: Kennett, J. P., Houtz, R. E., and et al., DSDP Initial Reports, Part III, 17, 743-755, doi:10.2973/dsdp.proc.29.117.1975, 1975.

Shipboard Scientific Party: Site 1052, in: Proceedings of the Ocean Drilling Program: College Station, TX (Ocean Drilling Program), edited by: Norris, R. D., Kroon, D., Klaus, A., and et al., Initial Reports, 171B, 241-319, doi:10.2973/odp.proc.ir.171b.106.1998, 1998.

Shipboard Scientific Party: Site 1171, in: Proceedings of the Ocean Drilling Program: College Station, TX (Ocean Drilling Program), edited by: Exon, N. F., Kennett, J. P., Malone, M. J., and et al., Initial Reports, 189, 1-176, doi:10.2973/odp.proc.ir.189.106.2001, 2001.

Shipboard Scientific Party: Site 1260, in: Proceedings of the Ocean Drilling Program: College Station, TX (Ocean Drilling Program), edited by: Erbacher, J., Mosher, D. C., Malone, M. J., and et al., Initial Reports, 207, 1-113, doi:10.2973/odp.proc.ir.207.107.2004, 2004.

Smith, M. E., Chamberlain, K. R., Singer, B. S., and Carroll, A. R.: Eocene clocks agree: Coeval 40Ar/39Ar, U-Pb, and astronomical ages from the Green River Formation, Geology, 38, 527-530, doi:10.1130/g30630.1, 2010.

Stickley, C. E., St John, K., Koc, N., Jordan, R. W., Passchier, S., Pearce, R. B., and Kearns, L. E.: Evidence for middle Eocene Arctic sea ice from diatoms and ice-rafted debris, Nature, 460, 376-379, doi:10.1038/nature08163, 2009.

St. John, K.: Cenozoic ice-rafting history of the central Arctic Ocean: Terrigenous sands on the Lomonosov Ridge, Paleoceanography, 23, PA1S05, doi:10.1029/2007PA001483, 2008.

Suganuma, Y. and Ogg, J. G.: Campanian through Eocene magnetostratigraphy of Sites 1257-1261, ODP Leg 207, Demerara Rise (western equatorial Atlantic), in: Proceedings of the Ocean Drilling Program, Scientific Results Volume 207, Chapter 3: Sedimentology and stratigraphy, edited by: Mosher, D. C., Erbacher,
J., and Malone, M. J., ODP, Sci. Results, 207: Initial Reports, 1-48, doi:10.2973/odp.proc.sr.207.102.2006, 2006.

Torrence C. and Compo, G.: Wavelet software, available at: http:// atoc.colorado.edu/research/wavelets/, last access: 12 May 2014.

Tripati, A., Backman, J., Elderfield, H., and Ferretti, P.: Eocene bipolar glaciation associated with global carbon cycle changes, Nature, 436, 341-346, doi:10.1038/nature03874, 2005.

Tripati, A. K., Eagle, R. A., Morton, A., Dowdeswell, J. A., Atkinson, K. L., Bahe, Y., Dawber, C. F., Khadun, E., Shaw, R. M. H., Shorttle, O., and Thanabalasundaram, L.: Evidence for glaciation in the Northern Hemisphere back to $44 \mathrm{Ma}$ from ice-rafted debris in the Greenland Sea, Earth Planet. Sc. Lett., 265, 112122, 2008.

Van Andel, T. H.: Mesozoic/cenozoic calcite compensation depth and the global distribution of calcareous sediments, Earth Planet. Sc. Lett., 26, 187-194, doi:10.1016/0012-821x(75)90086-2, 1975.

Vandenberghe, N., Hilgen, F. J., and Speijer, R. P.: The Paleogene Period, in: The Geological Timescale 2012, edited by: Gradstein, F. M., Ogg, J. G., Schmitz, M. D., and Ogg, G. M., Elsevier, 855922, doi:10.1016/B978-0-444-59425-9.00028-7, 2012.

Vonhof, H. B., Smit, J., Brinkhuis, H., Montanari, A., and Nederbragt, A. J.: Global cooling accelerated by early late Eocene impacts?, Geology, 28, 687-690, doi:10.1130/00917613(2000)28<687:gcabel>2.0.co;2, 2000.

Wade, B. S. and Pälike, H.: Oligocene climate dynamics, Paleoceanography, 19, PA4019, doi:10.1029/2004PA001042, 2004.

Walsh, S. L., Prothero, D. R., and Lundquist, D. J.: Stratigraphy and paleomagnetism of the middle Eocene Friars Formation and Poway Group, southwestern San Diego County, California in: The Terrestrial Eocene-Oligocene Transition in North America, edited by: Prothero, D. R. and Emry, R. J., Cambridge University Press, Cambridge, 120-151, doi:10.1017/CBO9780511665431.007, 1996.

Westerhold, T. and Röhl, U.: High resolution cyclostratigraphy of the early Eocene - new insights into the origin of the Cenozoic cooling trend, Clim. Past, 5, 309-327, doi:10.5194/cp-5309-2009, 2009.

Westerhold, T. and Röhl, U.: Orbital pacing of Eocene climate during the Middle Eocene climate optimum and the chron C19r event: Missing link found in the tropical western Atlantic, Geochem. Geophy. Geosy., 14, 4811-4825, doi:10.1002/ggge.20293, 2013.

Westerhold, T., Röhl, U., Laskar, J., Bowles, J., Raffi, I., Lourens, L. J., and Zachos, J. C.: On the duration of magnetochrons $\mathrm{C} 24 \mathrm{r}$ and $\mathrm{C} 25 \mathrm{n}$ and the timing of early Eocene global warming events: Implications from the Ocean Drilling Program Leg 208 Walvis Ridge depth transect, Paleoceanography, 22, PA2201, doi:10.1029/2006PA001322, 2007.

Westerhold, T., Röhl, U., Donner, B., McCarren, H. K., and Zachos, J. C.: A complete high-resolution Paleocene benthic stable isotope record for the central Pacific (ODP Site 1209), Paleoceanography, 26, PA2216, doi:10.1029/2010pa002092, 2011.

Westerhold, T., Röhl, U., Wilkens, R., Pälike, H., Lyle, M., Jones, T. D., Bown, P., Moore, T., Kamikuri, S., Acton, G., Ohneiser, C., Yamamoto, Y., Richter, C., Fitch, P., Scher, H., Liebrand, D., and the Expedition 320/321 Scientists: Revised composite depth scales and integration of IODP Sites U1331-U1334 and ODP Sites 1218-1220, in: Proceedings of the Integrated Ocean 
Drilling Program, 320/321, edited by: Pälike, H., Lyle, M., Nishi, H., Raffi, I., Gamage, K., Klaus, A., and the Expedition 320/321 Scientists, doi:10.2204/iodp.proc.320321.201.2012, 2012a.

Westerhold, T., Röhl, U., and Laskar, J.: Time scale controversy: Accurate orbital calibration of the early Paleogene, Geochem. Geophy. Geosy., 13, Q06015, doi:10.1029/2012gc004096, 2012b.

Westerhold, T., Röhl, U., Pälike, H., Wilkens, R., Wilson, P. A., and Acton, G.: Orbitally tuned time scale and astronomical forcing in the middle Eocene to early Oligocene determined on ODP and IODP sediment cores, Unpublished dataset \#821903, Supplement to: Westerhold, T., Röhl, U., Pälike, H., Wilkens, R., Wilson, P. A., and Acton, G.: Orbitally tuned time scale and astronomical forcing in the middle Eocene to early Oligocene, Clim. Past Discuss., 9, 66356682, doi:10.5194/cpd-9-6635-2013, 2013, available online in the WDC-MARE PANGAEA database: http://doi.pangaea.de/ 10.1594/PANGAEA.821903, last access: 12 May 2014, 2013.

Wilkens, R., Dickens, G. R., Tian, J., Backman, J., and the Expedition 320/321 Scientists: Data report: revised composite depth scales for Sites U1336, U1337, and U1338, in: Proceedings of the Integrated Ocean Drilling Program, 320/321, edited by: Pälike, H., Lyle, M., Nishi, H., Raffi, I., Gamage, K., Klaus, A., and the Expedition 320/321 Scientists, doi:10.2204/iodp.proc.320321.201.2012, 2013.
Xiao, G. Q., Abels, H. A., Yao, Z. Q., Dupont-Nivet, G., and Hilgen, F. J.: Asian aridification linked to the first step of the EoceneOligocene climate Transition (EOT) in obliquity-dominated terrestrial records (Xining Basin, China), Clim. Past, 6, 501-513, doi:10.5194/cp-6-501-2010, 2010.

Zachos, J., Pagani, M., Sloan, L., Thomas, E., and Billups, K.: Trends, Rhythms, and Aberrations in Global Climate $65 \mathrm{Ma}$ to Present, Science, 292, 686-693, doi:10.1126/science.1059412, 2001.

Zachos, J. C., Stott, L. D., and Lohmann, K. C.: Evolution of early Cenozoic marine temperatures, Paleoceanography, 9, 353-387, doi:10.1029/93PA03266, 1994.

Zachos, J. C., Quinn, T. M., and Salamy, K. A.: High-resolution $\left(10^{4}\right.$ years) deep-sea foraminiferal stable isotope records of the Eocene-Oligocene climate transition, Paleoceanography, 11, 251-266, doi:10.1029/96PA00571, 1996.

Zachos, J. C., McCarren, H., Murphy, B., Röhl, U., and Westerhold, T.: Tempo and scale of late Paleocene and early Eocene carbon isotope cycles: Implications for the origin of hyperthermals, Earth Planet. Sc. Lett., 299, 242-249, doi:10.1016/j.eps1.2010.09.004, 2010. 